\title{
Immune Recognition of Fungal Polysaccharides
}

\author{
Brendan D. Snarr ${ }^{1,2}$, Salman T. Qureshi ${ }^{3,4}$ (i) and Donald C. Sheppard ${ }^{1,2, *}$ \\ 1 Department of Microbiology and Immunology, McGill University, Montreal, QC H3A 2B4, Canada; \\ brendan.snarr@mail.mcgill.ca \\ 2 Department of Medicine, Infectious Diseases and Immunity in Global Health Program, \\ Centre for Translational Biology, McGill University Health Centre, Montreal, QC H4A 3J1, Canada \\ 3 Meakins-Christie Laboratories, Department of Medicine and Division of Experimental Medicine, \\ McGill University, Montréal, QC H4A 3J1, Canada; salman.qureshi@mcgill.ca \\ 4 Department of Critical Care and Research, Institute of the McGill University Health Centre, Montréal, \\ QC H4A 3J1, Canada \\ * Correspondence: don.sheppard@mcgill.ca; Tel.: +1-514-934-1934 (ext. 36104)
}

Received: 31 July 2017; Accepted: 23 August 2017; Published: 28 August 2017

\begin{abstract}
The incidence of fungal infections has dramatically increased in recent years, in large part due to increased use of immunosuppressive medications, as well as aggressive medical and surgical interventions that compromise natural skin and mucosal barriers. There are relatively few currently licensed antifungal drugs, and rising resistance to these agents has led to interest in the development of novel preventative and therapeutic strategies targeting these devastating infections. One approach to combat fungal infections is to augment the host immune response towards these organisms. The polysaccharide-rich cell wall is the initial point of contact between fungi and the host immune system, and therefore, represents an important target for immunotherapeutic approaches. This review highlights the advances made in our understanding of the mechanisms by which the immune system recognizes and interacts with exopolysaccharides produced by four of the most common fungal pathogens: Aspergillus fumigatus, Candida albicans, Cryptococcus neoformans, and Histoplasma capsulatum. Work to date suggests that inner cell wall polysaccharides that play an important structural role are the most conserved across diverse members of the fungal kingdom, and elicit the strongest innate immune responses. The immune system senses these carbohydrates through receptors, such as lectins and complement proteins. In contrast, a greater diversity of polysaccharides is found within the outer cell walls of pathogenic fungi. These glycans play an important role in immune evasion, and can even induce anti-inflammatory host responses. Further study of the complex interactions between the host immune system and the fungal polysaccharides will be necessary to develop more effective therapeutic strategies, as well as to explore the use of immunosuppressive polysaccharides as therapeutic agents to modulate inflammation.
\end{abstract}

Keywords: polysaccharide; immune receptor; fungal cell wall; Aspergillus fumigatus; Candida albicans; Cryptococcus neoformans; Histoplasma capsulatum

\section{Introduction}

Over the past several decades, there has been a marked increase in the use of immunosuppressive therapy for the treatment of haematologic malignancies, stem cell and solid organ transplantation, and rheumatologic disorders. In parallel, there has also been an increased use of novel surgical techniques, indwelling central venous catheters, and other prosthetic devices in hospitalized patients. These changes in health care, combined with the HIV epidemic, have resulted in a rapid expansion in the number of patients with acquired defects in innate, acquired, and mucosal immunity. This patient population is at increased risk for the acquisition of a wide range of fungal infections, leading to a resurgence of interest in the development of novel antifungal therapeutics. 
One approach to combating fungal infections is to augment host recognition and immune response to these organisms. Fungal cell wall glycans and exopolysaccharides play a critical role in these fungal-host interactions. The cell wall is the first point of physical contact between the pathogen and host cells, and fungal polysaccharides have been identified both as ligands for innate immune receptors, and antigens that can stimulate adaptive immune responses. This review will summarize our current understanding of the immune response to fungal exopolysaccharides, and the molecular mechanisms underlying the recognition of these glycans. We have focussed our attention on four of the most common medically relevant fungi: Candida albicans, Aspergillus fumigatus, Cryptococcus neoformans, and Histoplasma capsulatum (Figure 1). Studies of immune interactions with the polysaccharides produced by these organisms reveals a common theme. Polysaccharides that are common to multiple fungi, and play a major role in cell wall structure, are associated with the strongest host immune responses through interactions with soluble and cell-associated pattern recognition receptors. However, medically relevant fungi have also developed unique exopolysaccharides that often serve to mask the more conserved glycans from detection by the host, and can even directly downregulate inflammatory responses. Gaps in our current understanding of these host-glycan interactions, and potential areas for future research, will be highlighted.
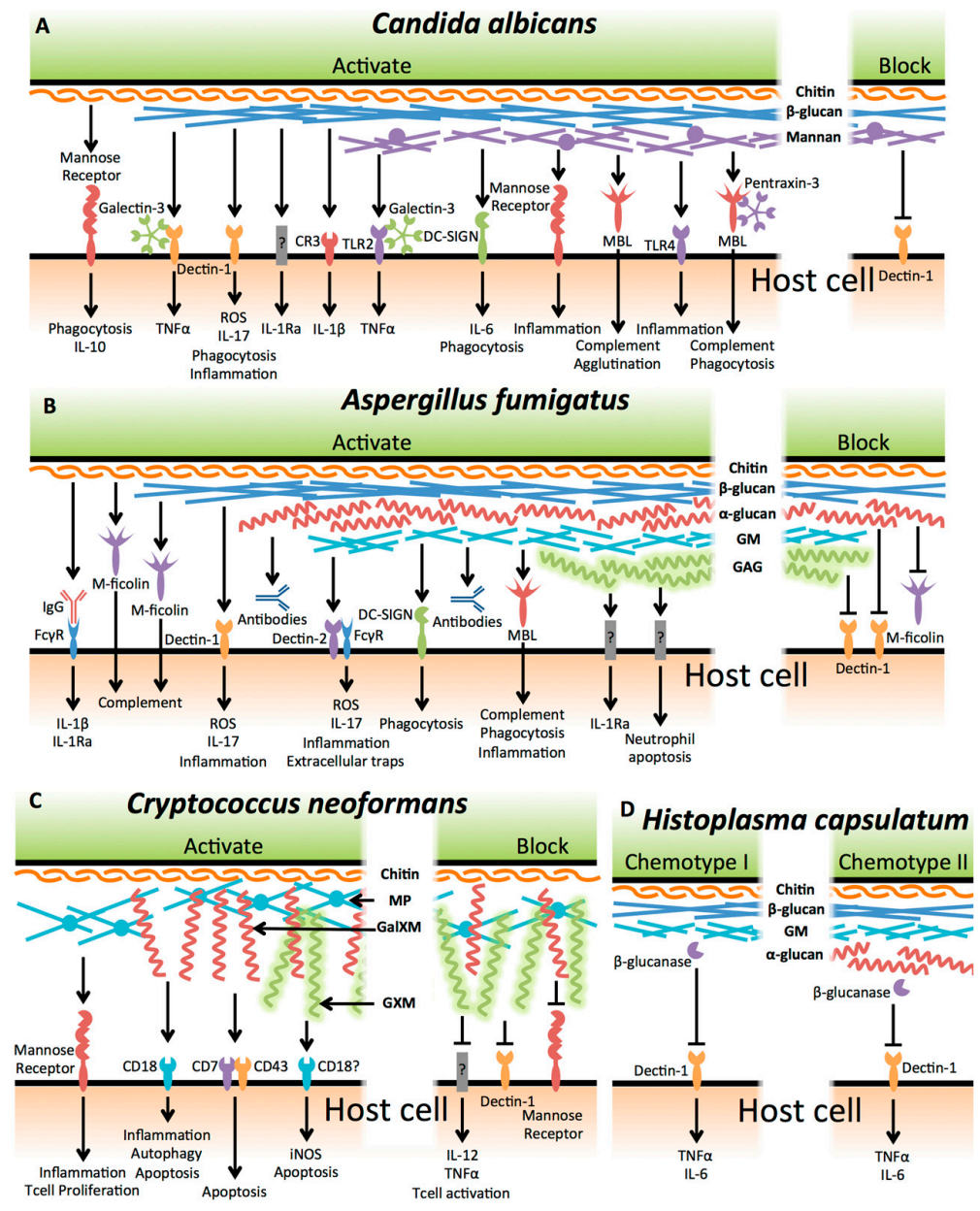

Figure 1. Graphical overview of interactions between fungal polysaccharides and host elements. (A) Candida albicans; (B) Aspergillus fumigatus; (C) Cryptococcus neoformans; and (D) Histoplasma capsulatum. Abbreviations used: CR3, complement receptor 3; $M B L$, mannose-binding lectin; GM, galactomannan; GAG, galactosaminogalactan; MP, mannoprotein; GalXM, galactoxylomannan; GXM, glucuronoxylomannan. Green indicates fungal cell, and tan, the host cell. 


\section{Candida albicans}

Candida albicans is a commensal yeast commonly found in the gastrointestinal tract of healthy individuals. However, C. albicans is also an opportunistic pathogen that is the most common cause of invasive fungal infection in hospitalized patients [1]. Risk factors for invasive candidiasis include the use of broad-spectrum antibiotics that lead to $C$. albicans overgrowth, surgical and medical interventions that breach normal mucosal barriers to Candida invasion, and immunosuppressive illnesses or therapies that impair host immune response [2]. Additionally, Candida can form biofilms on biomedical devices, including urinary and vascular catheters [3]. During infection, C. albicans can switch morphologies between yeast cells, pseudohyphae and hyphae [4]. This ability to undergo morphogenesis is a critical virulence factor of $C$. albicans, and allows it to exploit a variety of environmental niches within the host [4]. The interactions of the host immune system with C. albicans glycans are the best studied among the medically relevant fungi, and have greatly advanced our understanding of innate immune recognition of these organisms.

\subsection{Beta-Glucan}

$\beta$-glucans are key structural polysaccharides found largely within the $C$. albicans inner cell wall. $\beta$-(1,3)-linked glucans are the most abundant of these glucans, with shorter chains of $\beta$-(1,6)-glucan that serve to cross-link the inner and outer cell wall [5]. $\beta-(1,3)$-glucans are pathogen associated molecular pattern (PAMP) ligands that are recognized by the pattern recognition receptor (PRR) dectin-1 (also known as CLEC7A) [6]. This interaction is the best studied of all fungal-innate immune interactions, and is common to most pathogenic fungi.

Dectin-1 is a transmembrane C-type lectin that is primarily expressed on the surface of immune cells, such as dendritic cells, alveolar macrophages, and neutrophils. The extracellular portion of dectin-1 consists of a carbohydrate recognition domain (CRD) atop a stalk region, while the intracellular portion contains an immunoreceptor tyrosine-based activation motif (ITAM) involved in signalling [7]. The CRD of dectin-1 recognizes $\beta$-(1,3)-glucan fragments that are a minimum of seven glucose residues long [8]. Dectin- 1 activation is proportional to $\beta$-glucan polymer length, and it has been suggested that dectin- 1 activation requires receptor clustering as part of the phagocytic synapse $[8,9]$. Dectin- 1 signalling induces phosphorylation of Syk and IKB, and translocation of NF- $\mathrm{KB}$ to the nucleus $[10,11]$, as well as Syk-independent signalling through Raf1 activation [12]. Dectin-1 activation controls a wide range of immune responses, including regulation of leukocyte phagocytosis, recruitment of Toll-like receptor (TLR) 9 to phagolysosomes, phagolysosome maturation, activation of autophagy, production of reactive oxygen species (ROS), activation of the inflammasome, and induction of pro- and anti-inflammatory cytokine secretion ([13,14], and reviewed in [15]).

Dectin-1 signalling in response to $\beta$-glucan can be modulated by interaction with other host proteins. The soluble galactose-specific lectin galectin-3 (previously known as Mac-2, $\varepsilon \mathrm{BP}$, or CBP30/35) physically interacts with dectin-1, likely through binding of glycosylated domains of the receptor to form multivalent oligomers that enhance clustering and activation of dectin-1 [16]. Galectin-3 exists in both a cytoplasmic and secreted form, and it remains to be determined if interaction of this lectin with dectin-1 occurs in the intracellular or extracellular space. Galectin-3 knockdown and overexpression studies in macrophages suggest that galectin- 3 interaction with dectin- 1 augments TNF production in response to $C$. albicans $\beta$-glucan [17]. However, the significance of this specific interaction is unclear, since, as detailed below, galectin-3 also interacts with C. albicans mannans [18], and there are conflicting reports as to the role of galectin-3 in host defence in vivo. A recent study reported that galectin-3 deficiency in mice increased resistance to C. albicans infection, and that intracellular galectin-3 suppressed Syk signalling within neutrophils to decrease ROS production [19]. These results contrast with an earlier report in which galectin-3 deficiency was associated with increased susceptibility of mice to C. albicans infection [20]. The molecular mechanisms underlying these conflicting studies are unknown, but may reflect different roles of intracellular and extracellular galectin- 3 in the modulation of immune responses. 
Other host receptors have been found to participate in the recognition and response to $\beta$-glucan. Complement receptor $3\left(C R 3\right.$, also known as Mac-1 and integrin $\left.\alpha_{M} \beta_{2}\right)$ enhances fungal responses through recognition of $\beta$-(1,6)-glucan [21]. In mouse bone marrow-derived neutrophils, CR3 expression is upregulated following dectin-1 recognition of $\beta$-glucan particles, resulting in phagocytosis of the particles and ROS production [22]. While CR3 is not required for phagocytosis of $\beta$-glucan particles by mouse peritoneal macrophages [22], IL-1 $\beta$ release by mouse bone marrow-derived macrophages (BMDMs) and bone marrow derived dendritic cells (BMDCs), in response to purified $\beta$-glucan and heat-killed C. albicans, is dependent on CR3 [23]. Consistent with these findings, CR3-deficent mice exhibit higher mortality and fungal burden compared to wild-type animals, when challenged with C. albicans, highlighting the importance of this receptor in host defence [22].

It is likely that other host receptors participate in the recognition of $\beta$-glucan. For example, $\beta$-glucan on the surface of $C$. albicans hyphae was reported to induce the production of IL-1 receptor antagonist (IL-1Ra) by peripheral blood mononuclear cells (PBMCs) via a dectin-1 and CR3-independent pathway [24]. While the mechanism of IL-1Ra induction is currently not well understood, inhibition of Akt and PI3K significantly reduced IL-1Ra production [24]. The identification and characterization of novel $\beta$-glucan recognition receptors is an area of great interest for future studies.

There is also evidence to suggest that some $C$. albicans strains are recognized by the host by dectin-1/ $\beta$-glucan independent mechanisms. Support for this hypothesis comes from a screen of 14 C. albicans strains from a range of clades, which were analyzed for their ability to stimulate cytokine release by human peripheral blood mononuclear cells (PBMCs) [25]. One strain induced PBMC IL-1 $\beta$ production that was inhibited by blocking of the mannose receptor (see below), but was unaffected by dectin-1 blockade [25]. Interestingly, this strain was hypovirulent in an intravenous mouse infection model [26], and failed to stimulate KC and MIP-2 production by M-1 murine renal epithelial cells, or mediate cellular damage in vitro [27]. Taken together, these findings suggest that some strains of C. albicans have developed adaptations to evade dectin- 1 detection, but these changes are associated with a loss of virulence.

In addition to natural recognition of $\beta$-glucan by the innate immune system, efforts have been made to use these glycans to augment adaptive immune responses against fungi. A $\beta$-glucan vaccine was generated by conjugating laminarin, composed of a $\beta$-(1,3)-glucan backbone with $\beta-(1,6)$-glucan branches isolated from the alga Laminaria digitata, to the diptheria toxoid CRM197 [28]. Immunization with this antigen increased mouse survival from 10 to $70 \%$, as compared to the adjuvant alone, in a model of systemic candidiasis [28]. Protection was antibody-mediated, as treating naïve mice with either serum from vaccinated mice, or a monoclonal IgG antibody raised against the $\beta$-glucan antigen, was effective at limiting fungal burden and improving survival. These antibodies reduced C. albicans adherence to human epithelial cells, as well as inhibited fungal growth in vitro [28,29]. The $\beta$-glucan vaccine provided only modest protection in a model of vaginal candidiasis, likely due to poor penetration of $\beta$-glucan-specific IgG antibodies to the vaginal mucosa [30]. However, vaccinated mice exhibited increase resistance to intravenous challenge with Aspergillus fumigatus [28] and intravenous challenge with Cryptococcus neoformans [31], highlighting the potential of $\beta$-glucan immunization to protect against a broad range of fungal pathogens.

\subsection{Mannan}

The outer layer of the $C$. albicans cell wall is composed of an array of heavily mannosylated proteins that are glycosylphosphatidylinositol (GPI)-modified and cross-linked to $\beta-(1,6)$-glucans $[32,33]$. Gas chromatography and nuclear magnetic resonance studies have suggested that $N$-linked mannans are large branched structures that consist primarily of an $\alpha-(1,6)$-mannose backbone with $\alpha$-(1,2)-oligomannose sidechains that are commonly capped with $\beta$-(1,2)-linked mono-, di-, tri, or tetramannans [34]. Genetic studies have suggested that phospholipomannans comprised of $\beta-(1,2)$-oligomannans can also be attached to the $N$-linked mannans via $\beta$-(1,2)-mannosyltransferases [35]. In contrast, $O$-linked mannans of $C$. albicans are primarily linear $\alpha-(1,2)$-oligomannans [34]. The relative abundance and composition 
of the mannans differs between $C$. albicans yeast and hyphae, with reduced phosphodiesterification of the $\beta-(1,2)$-oligomannans and decreased branching of the $\alpha-(1,6)$ backbone in hyphae [34].

Multiple studies have demonstrated that the outer mannan layer plays an important role in concealing $\beta$-glucans from host immune detection. Treatment of mouse BMDCs with heat-killed yeast producing $N$-linked mannans deficient in $\beta$-(1,2)-mannan, resulted in the release of higher levels of pro-inflammatory cytokines, such as IL-6, IL-12p40, IL-23, and TNF $\alpha$, as compared with wild type C. albicans [36]. Similarly, live yeast cells deficient in mannan branching induced greater levels of IL-1 $\beta$, IL-10, and TNF $\alpha$ secretion by human PBMCs, largely due to enhanced $\beta$-glucan exposure [37]. Deletion of $\alpha-(1,6)$-mannosyltransferase in C. albicans produced a strain with severely-truncated $N$-linked mannans and increased $\beta$-glucan exposure, which resulted in higher IL- 6 and TNF $\alpha$ production by mouse peritoneal macrophages [38]. Similarly, a C. albicans strain deficient in O-linked mannans exhibited increased $\beta$-glucan exposure, and was unable to prevent phagolysosome maturation in RAW and J774 macrophage cell lines, as well as mouse peritoneal macrophages, resulting in a reduced ability of C. albicans to lyse and escape from these cells [39]. Finally, chemical removal of the mannan layer of the cell wall resulted in enhanced activation of the alternative pathway of the complement cascade, as determined by the ability of human neutrophils to phagocytize yeast cells in the presence of human serum [40].

Although mannans play an important role in immune evasion, a number of host receptors can directly recognize mannans and augment host defences. The C-type lectin, dendritic cell-specific intercellular adhesion molecule 3-grabbing nonintegrin (DC-SIGN, also known as CD209), was found to bind to $N$-linked mannans [41]. DC-SIGN is comprised of an extracellular stalk consisting of multiple CRDs, and an intracellular domain containing motifs that participate in internalization [42]. The CRD of DC-SIGN shows specificity for mannose-containing oligosaccharides [43]. These multiple CRDs are thought to aid in receptor multimerization and clustering [44]. Consistent with the internalization motifs on the cytosolic domain, DC-SIGN is thought to function largely as an endocytic receptor, and is primarily expressed on professional antigen-presenting cells, such as macrophages and dendritic cells [42]. Phagocytosis of C. albicans yeast cells by human monocyte-derived dendritic cells, and release of IL-6, is dependent on DC-SIGN and N-linked mannans [41,45].

$\mathrm{N}$-linked mannans are also recognized by a number of other receptors. The mannose receptor (MR, also known as CD206), a transmembrane lectin found predominantly in macrophages [46], can recognize terminal mannose structures [47]. While the MR is primarily expressed on the cell surface, a soluble form can also be released through proteolytic cleavage [47]. TLR4, on both human mononuclear cells and murine macrophages, recognizes $O$-linked mannans on the surface of C. albicans yeast cells [46]. Optimal release of TNF $\alpha$, IL-6, IL-10, and interferon (IFN) $\gamma$ by these cells required recognition of both $N$ - and O-linked mannans by MR and TLR4, respectively [46]. Human mononuclear cells incubated with $C$. albicans deficient in either $N$ - or O-linked mannans produced lower levels of cytokines, which could be further reduced with blocking antibodies targeting the receptor for the other mannan structure [46]. Finally, dectin-2 (also known as CLEC6A or CLECSF10), a C-type lectin commonly expressed by tissue macrophages, dendritic cells, and PBMCs, has also been implicated in the recognition of C. albicans mannans [48]. The CRD of dectin-2 is specific for $\alpha-(1,2)$-mannan structures, which are significantly masked by the $\beta$-linked mannan caps [49]. Mouse peritoneal macrophages exhibited increased IL-6 and KC release in vitro, in response to C. albicans lacking $\beta$-mannans, in a dectin-2-dependent manner [49]. Importantly, dectin-2 lacks a cytoplasmic signalling motif, and therefore, must associate with other receptors to transduce signals. Dectin-2 forms heterodimers with dectin-3 (also known as CLEC4D or CLECSF8), another C-type lectin that recognizes $\alpha$-mannans, to activate intracellular signalling cascades [50]. This heterodimeric complex is thought to recruit the $\mathrm{Fc} \gamma$ receptor $(\mathrm{Fc} \gamma \mathrm{R})$ to further activate signalling cascades [50-52]. RAW264.7 macrophages, stably expressing both dectin-2 and dectin-3, produced greater amounts of TNF- $\alpha$ in response to purified $\alpha$-mannans, than did cells expressing only one of the receptors [50]. Dectin-2-deficient mice are hypersusceptible to intravenous challenge with both $C$. albicans and 
Candida glabrata, exhibiting decreased survival, greater kidney fungal burden, and reduced production of $\mathrm{T}$ helper $\left(\mathrm{T}_{\mathrm{H}}\right)$ 1- and $\mathrm{T}_{\mathrm{H}}$ 17-derived cytokines by splenocytes, as compared to the wild type control mice [49,53]. Dectin-3-deficient mice were also hypersusceptible to C. albicans intravenous infection, with higher mortality and kidney fungal burden as compared with wild type mice [50], illustrating the importance of the dectin-2/dectin-3 heterodimer in recognizing $\alpha$-mannans and mounting a successful anti-fungal immune response.

Soluble receptors can also interact with Candida mannans. The $\beta$-(1,2)-mannan sidechains of the $N$-linked mannans on $C$. albicans yeast cells were specifically recognized by galectin-3 [18]. While phagocytosis by J774 macrophages was not found to be dependent on galectin-3, the interaction between galectin-3 and $\beta-(1,2)$-mannan was required for optimal TNF $\alpha$ release by both J774 cells and mouse peritoneal macrophages [18]. This signalling occurred via TLR2 activation in macrophages, and may provide a mechanism for the host to discriminate between pathogenic $C$. albicans and the commensal Saccharomyces cerevisiae, which lacks these $\beta-(1,2)$-mannan sidechains [18]. Intriguingly, it has been reported that binding of human recombinant galectin-3 to $\beta-(1,2)$-mannan can directly kill C. albicans yeast cells in the absence of any other immune effectors [54], although the mechanisms underlying this observation remain unknown.

Mannose-binding lectin (MBL, also known as MBL2) is likely another important host receptor for $C$. albicans mannans. MBL is a soluble circulating collectin-class lectin of hepatic origin that forms helical quaternary structures that increase its avidity for carbohydrates [55]. Upon binding to carbohydrates, MBL induces complement activation via complex formation with MBL-associated serine proteases (MASPs) [56]. While the precise carbohydrate ligand remains unclear, human recombinant MBL bound strongly to budding and young yeast cells, as well as hyphae [57]. This binding was temperature-specific, as MBL bound strongly to mature yeast grown at $37^{\circ} \mathrm{C}$, but not to yeast grown at $23^{\circ} \mathrm{C}$ [57]. Mannans purified from cultures grown at $23^{\circ} \mathrm{C}$ were recognized by MBL, suggesting that failure to detect MBL ligand at this temperature is due to masking by another polymer [57]. As with galectin-3, MBL binds poorly to $S$. cerevisiae, suggesting a role in discriminating between commensal and pathogenic fungi [57]. Human MBL initiates the agglutination of $C$. albicans hyphae [58], and can recruit additional host factors to aid in immune recognition of these fungal structures. Binding of MBL to the cell wall resulted in enhanced deposition of complement proteins $\mathrm{C} 4$ and $\mathrm{C} 3 \mathrm{~b}$ from normal human serum, and augmented phagocytosis of yeast by human blood polymorphonuclear cells (PMN) [59], but not human monocyte-derived DCs. These actions are likely due to heterocomplexes formed between MBL and other serum proteins, as complexes of MBL and either pentraxin-3 or serum amyloid $\mathrm{P}$, result in $\mathrm{C} 4$ and $\mathrm{C} 3 \mathrm{~b}$-mediated human PMN phagocytosis of $C$. albicans yeast [60]. As with galectin-3, MBL binding to $C$. albicans also directly inhibits growth of the fungus, suggesting that they may bind similar glycans on the fungal cell wall [58]. The MBL-pentraxin-3 heterocomplex activates complement-mediated killing through deposition of complement protein C1q [60]. Taken together, these findings suggest that MBL mediates a complex anti-C. albicans response through both complement-mediated killing and opsonisation. Consistent with these observations, prophylactic treatment of mice with MBL improves survival following intravenous C. albicans challenge [57]. Furthermore, genome-wide association studies have identified polymorphisms in the human $M B L$ gene, with heightened susceptibility to vulvovaginal candidiasis and increased rates of recurrence of this condition [61], suggesting a role for $M B L$ in mucosal immunity against $C$. albicans.

Several studies have evaluated the virulence of mannan-deficient strains of $C$. albicans $[38,46,62]$. Strains deficient in $O$-linked mannan had slower growth rates and greater antifungal susceptibility, suggesting that $O$-linked mannosylation may also be required for normal mannoprotein function. Consistent with these observations, $O$-linked mannan-deficient strains exhibited attenuated virulence in a mouse model of systemic infection [62]. Mice infected with $N$-linked mannan-deficient $C$. albicans exhibited higher survival and lower kidney fungal burden, as well as reduced levels of kidney IL-6 and TNF $\alpha$, as compared to those infected with wild-type C. albicans [46]. Similarly, despite no observed defect in growth rate, an $\alpha-(1,6)$-mannosyltransferase-deficient mutant that produces a 
severely-truncated $N$-linked mannan backbone, also exhibited attenuated virulence in a mouse model of systemic candidiasis, in association with increased $\mathrm{T}_{\mathrm{H}} 1$ and $\mathrm{T}_{\mathrm{H}} 17$ responses and increased kidney levels of IFN- $\gamma$, IL-6, and IL-17 [38]. Thus, despite the presence of a range of host receptors that can mediate recognition of Candida mannans, these animal studies suggest that the virulence promoting characteristics of these polysaccharides predominate during invasive infection.

\subsection{Chitin}

Chitin is a ubiquitous exopolysaccharide composed of $\beta-(1,4)-N$-acetylglucosamine that is produced by a wide array of arthropods, parasites, and fungi. Chitin is found within the innermost layer of the C. albicans cell wall [33], where it plays an important role in maintaining cell rigidity and resistance to physical stress. While it is one of the least well-studied cell wall components of C. albicans, several recent studies using purified C. albicans chitin have begun to shed light onto the immunomodulatory effects of this glycan. Pure chitin is a strong activator of the complement cascade, and can induce cleavage of complement protein $\mathrm{C} 3$ via the alternative complement pathway to produce C3a, a potent anaphylatoxin [63]. Human PBMCs pre-treated with chitin produced lower levels of the pro-inflammatory cytokines TNF $\alpha$, IL-6, and IL-1 $\beta$ in response to C. albicans yeast exposure [64]. Treatment of $C$. albicans with sub-therapeutic concentrations of caspofungin, which increased the surface exposure of chitin, also resulted in a reduced pro-inflammatory cytokine response [64]. While the authors reported no difference in $\beta$-glucan content in caspofungin-treated and untreated C. albicans [64], it is difficult to exclude the possibility that inhibitory effects of this agent on $\beta$-glucan synthesis may have also have contributed to these observations [65]. Treatment of mice with intranasal chitin induced release of IL- 25 and IL-33 by airway epithelial cells, resulting in type-2 innate lymphoid cell production of IL-5, and pulmonary recruitment of eosinophils and M2 macrophages [66]. Intraperitoneal administration of chitin induced eosinophilia and suppressed the TNF $\alpha$ response to LPS challenge in mice [67]. Similarly, purified C. albicans chitin directly enhanced the release of the anti-inflammatory cytokine IL-10 by human PBMCs [67]. IL-10 production in these studies was dependent on the MR, and involved TLR9 and NOD2 activation [67]. Chitin-mediated anti-inflammatory responses have been postulated as a mechanism of resolving inflammation when non-viable chitin "ghosts" remain following successful killing of the C. albicans yeast cells [67].

\subsection{Candida albicans Biofilms}

During infection, C. albicans commonly grows in biofilms formed on prosthetic devices or mucosal surfaces $[68,69]$. While the majority of studies examining the host response to $C$. albicans have been performed using planktonic cells, there have been recent efforts to examine the immune response to biofilm-grown organisms (reviewed in [70]). Cytokine production by PBMCs has been reported to differ between biofilm and planktonic cells with high levels of IL-1 $\beta$, IL-10, and MCP-1, and lower IL-6 and MIP1 $\beta$ production, in response to biofilm-grown organisms [71]. Impaired phagocytosis and killing of biofilm-associated organisms by PBMCs [71], monocytes [72], and neutrophils [72-74] have all been reported. Impaired activation of neutrophils has been linked to $\beta$-glucans [74], as well as the GPI-anchored cell wall protein Hyr1 [75]. Candida biofilms formed on mucosal surfaces are characterized by the infiltration of abundant neutrophils [76-80], a process that has been linked to the production of chemotactic factors, such as alarmins, by epithelial cells in response to fungal colonization $[77,81-83]$.

\subsection{Non-albicans Candida Species}

While C. albicans are the most common species isolated from Candida infections, rates of infections with other Candida species are increasing [84]. Among these species, C. glabrata and C. parapsilosis are the most frequently implicated in nosocomial infections [84]. Differences in host-pathogen interactions between these strains have been reported in a number of studies. 
C. glabrata is more closely genetically related to the non-pathogenic yeast Saccharomyces cerevisiae, and produces surface mannans more closely related to this organism $[85,86]$. In contrast to C. albicans, disruption of mannosyltransferases that mediate synthesis of $N$-linked mannans enhanced the virulence of these strains [87], suggesting that recognition of these glycans by host PRRs is important in innate host defence. J774 macrophages phagocytosed C. glabrata more avidly than C. albicans [88], and C. glabrata survival within the phagosomes of macrophages has been linked to decreased chitin exposure [89]. Whether this chitin masking is a consequence of cell wall mannans remains to be determined.

Although less is known about the cell wall composition of $C$. parapsilosis, lectin staining suggests differences in chitin exposure as compared with C. albicans [90]. Deletion of the $\alpha 1,6$-mannosyltransferase, responsible for initiating $N$-linked mannan production, resulted in a strain that induced higher levels of pro-inflammatory cytokine production by PBMCs [91]. Increased cytokine production was associated with increased exposure of $\beta$-glucans, and was reduced by laminarin-mediated blocking of dectin-1 or with antibodies to TLR4 [91]. As with C. albicans, loss of $N$-linked mannans was associated with attenuated virulence [91]. In contrast, $\beta$-elimination trimming of $O$-linked mannans increased production of IL-10 by PBMCs stimulated with live wild type cells, and reduced pro-inflammatory cytokine induction by $\mathrm{N}$-linked mannan-deficient organisms [91]. Collectively, these observations suggest a pro-inflammatory role for $O$-linked mannans of $C$. parapsilosis, although further studies are required to validate these observations in vivo.

\section{Aspergillus fumigatus}

Aspergillus fumigatus is an ubiquitous mould that produces abundant airborne conidia. Every day, humans inhale up to one hundred of these conidia, which are largely eliminated by the airway cell mucociliary action or killed by pulmonary macrophages, before they undergo germination [92]. Dormant conidia are coated in a layer of hydrophobic rodlet proteins that are largely immunoinert and conceal cell wall polysaccharides from immune detection [93]. If conidia evade these initial immune defences, they begin to swell and shed this layer of hydrophobins, exposing deeper cell components. Swollen conidia then undergo germination to produce filamentous hyphae, which can invade host tissues and blood vessels [94]. The cell wall composition of each of these fungal growth stages differs [93], and as a result, the host exhibits stage-specific immune responses to A. fumigatus. Despite current antifungal therapies, the mortality of invasive aspergillosis remains between $50 \%$ and $90 \%$, highlighting the need for new treatment options for this infection [95]. Strategies targeting cell wall polysaccharide synthesis, and the immune response to these glycans, are two promising therapeutic approaches.

\subsection{Beta-Glucan}

Mutants devoid of $\beta$-glucan are viable, but produce leaky, fragile cell walls, and are markedly impaired in growth and development [96]. In resting conidia, $\beta$-glucan is concealed by a layer of hydrophobic proteins, termed rodlets [93]. During germination, conidia shed this rodlet layer to display high levels of surface exposed $\beta$-glucan [97], leading to an increased production of dectin-1-dependent CXCL1, CXCL2, and TNF $\alpha$ by BMDMs [98]. Alveolar macrophages isolated from dectin-1-deficient mice were impaired in their ability to produce proinflammatory cytokines, such as IL- $1 \alpha$, IL-1 $\beta$, TNF $\alpha$, MIP- $1 \alpha$, MIP-1 $\beta$, and KC in response to live A. fumigatus conidia after $24 \mathrm{~h}$ of growth [99], a finding that has been validated in vivo in an Aspergillus keratitis model [10]. Similarly, human monocyte-derived dendritic cells incubated with young hyphae exhibited significantly reduced expression of IL-12 and TNF $\alpha$ when treated with either dectin-1 blocking antibodies or transfected with dectin-1 silencing RNA [100]. Additionally, thioglycolate-elicited neutrophils from dectin-1-deficient mice produced lower levels of ROS when challenged with swollen A. fumigatus conidia, and exhibited impaired killing of the fungus in vitro [99]. As hyphae mature, $\beta$-glucan is again masked by the production of the exopolysaccharide galactosaminogalactan (discussed further below) [101]. 
Dectin-1 is required for normal production of IL-23 by dendritic cells in response to Aspergillus [102]. Production of IL-23 plays an important role in defence against fungal infection through stimulating neutrophil IL-17 production. Mice deficient in dectin-1 produced lower levels of IL-17A, exhibited reduced neutrophil recruitment to the site of infection, and had increased mortality following pulmonary challenge with A. fumigatus [99]. Dectin-1-dependent IL-23 secretion was also required for optimal IL-22 responses in a mouse model of pulmonary aspergillosis [99]. IL-22 induction was necessary for optimal IL- $1 \alpha$, IL-12 (both p40 and p70), CCL3, CCL4, and TNF $\alpha$ release, leading to control of fungal infection [103]. These findings have been corroborated with a model of fungal keratitis, where dectin- 1 was required for optimum IL-1 $\beta$ and KC production, and control of fungal growth [10]. These dectin-1-mediated responses are most important against germinating conidia and young hyphae, as $\beta$-glucans are cloaked by the exopolysaccharide galactosaminogalactan produced by growing hyphae (discussed further below) [97,101].

Dectin-1 also plays a role in facilitating the adaptive immune response to A. fumigatus. Dectin-1-deficiency resulted in alterations in A. fumigatus-specific T cell maturation following adoptive transfer and pulmonary challenge with A. fumigatus [104]. Analysis of bronchoalveolar lavage (BAL) fluid from these mice revealed a greater abundance of IL-17-producing T cells in wild-type mice than was found in dectin- 1 deficient animals in which IFN- $\gamma$-positive T cells were most abundant [104]. In a mouse model of A. fumigatus-induced allergy, production of IL-17, IL-4 and IL-13 by T cells was dectin-1-dependent, leading to increased airway resistance and allergic pathology [105]. These dectin-1-dependent effects were mediated by IL-22 production, illustrating that while this cytokine is beneficial in the context of acute $A$. fumigatus infection, it can be detrimental in allergic disease.

As with C. albicans, other host molecules are thought to participate in the detection and response to $\beta$-glucans during A. fumigatus infection. M-ficolin, also known as ficolin-1, is a member of the ficolin family of opsonins that mediate recognition of pathogens Escherichia coli and Staphylococcus aureus, and activation of the complement pathway [106]. Recombinant human M-ficolin binds to conidia and young hyphae of $A$. fumigatus, to $\beta$-(1,3)-glucan-containing $A$. fumigatus alkali-insoluble hyphal cell wall fraction (AIF) [107], and to purified $\beta$-(1,3)-glucan [108]. M-ficolin binding to AIF and purified $\beta$-(1,3)-glucan activates the lectin-dependent complement pathway in vitro [108], and enhances IL-8 secretion by A594 airway epithelial cells, when incubated in vitro with AIF [108]. A synergistic interaction between $\mathrm{M}$-ficolin and the soluble pattern recognition receptor pentraxin-3 has also been observed in vitro, resulting in greater M-ficolin binding to the $\beta$-glucan of A. fumigatus, and C4 deposition and activation of the complement cascade [109]. While M-ficolin has been detected in granulocytes and monocytes at the periphery of pulmonary aspergillomas in humans [108], the role of M-ficolin during experimental A. fumigatus infection has not been studied.

\subsection{Galactomannan}

A. fumigatus galactomannan (GM), is composed of an $\alpha-(1,2)(1,6)$-mannopyranose backbone with short branches of $\beta-(1,5)$-oligogalactofuranose connected by $\beta-(1,3)$ and $\beta-(1,6)$ linkages [110]. GM is found in the hyphal cell wall, conjugated to both proteins [111] and glucans [112], as well as in a soluble form that is shed into the environment. Additionally, a second species of GM, produced by the action of a unique set of mannosyltransferases, is present exclusively in the conidia, where it appears to be involved in conidial separation during sporulation [112]. A mutant lacking these mannosyltransferases produced conidia with altered cell wall organization and reduced viability [112]. The solubility of GM, as well as its relative specificity for Aspergillus species, makes it a useful diagnostic marker of Aspergillus infection $[113,114]$.

The mannan and galactofuranose components of GM are differentially recognized by the host. The mannan core closely resembles cell wall mannans of other fungi, and as a consequence, interacts with many of the host mannose receptors described above. The best described receptor for the mannan core is DC-SIGN [115]. Antibodies to DC-SIGN dramatically reduce binding and phagocytosis of conidia by human monocyte-derived dendritic cells [116]. While the ligand interacting with DC-SIGN 
was not defined in this study, purified A. fumigatus GM was found to block binding of conidia to dendritic cells $[116,117]$. Surprisingly, DC-SIGN played no role in the cytokine response of human monocyte-derived dendritic cells to A. fumigatus young hyphae, as DC-SIGN knockdown experiments revealed no change in TNFA or IL12 gene expression, as compared with vector controls [100]. There are several possible interpretations for these results. It is possible that Aspergillus mannan is not a potent inducer of cytokine responses, or that other mannan receptors can compensate for the loss of DC-SIGN. An alternate, intriguing hypothesis is that DC-SIGN is more specific for the recognition of the unique species of soluble GM found in conidia, which were not tested in this study [112].

Dectin-2 also plays an important role in the detection of the $\alpha$-mannan backbone of GM. Binding of swollen conidia and hyphae by THP-1 macrophages is dectin-2-dependent, leading to Syk-dependent signalling and NF- $\mathrm{kB}$-specific activation [118]. These NF- $\mathrm{kB}-$ dependent responses include release of IL-1 $\beta$, IL-10, IL-23, and TNF $\alpha$, as well as the generation of ROS [118]. These responses were not observed in response to resting conidia, likely due to the rodlet layer of the conidia masking cell wall GM [98]. Consistent with this hypothesis, rodlet-deficient mutants induced higher levels of CXCL2 and TNF $\alpha$ production by BMDMs in a dectin-2-dependent manner [98]. Recognition of $A$. fumigatus hyphae by human plasmacytoid dendritic cells was also found to be dectin- 2 dependent, leading to release of TNF $\alpha$ and IFN- $\alpha$ [119], and production of extracellular traps by these cells [119]. In mouse bone marrow neutrophils, dectin-2 surface expression was induced in response to IL-6 and IL-23, where it augmented IL-17 release, leading to increased killing of A. fumigatus hyphae in vitro [120]. Finally, human data support a role for dectin-2 in the pathogenesis of invasive aspergillosis, as increased expression of dectin-2, largely restricted to macrophages, was observed during pulmonary infection [121].

Although MBL binding to GM has not been specifically demonstrated, purified MBL binds to the surface of A. fumigatus resting conidia [122], an interaction that could be inhibited with mannose, $\mathrm{N}$-acetylglucosamine, and EDTA [123]. Human corneal epithelial cells up-regulate and secrete MBL in response to A. fumigatus antigens [124], and MBL enhances phagocytosis of conidia, and killing of A. fumigatus hyphae by human PMNs in the presence of serum [125]. As with C. albicans, interactions between MBL and A. fumigatus activate the complement cascade, however, there are conflicting reports in the literature as to whether this occurs via C4 deposition [125], or the C2 bypass mechanism [122].

Mouse models have suggested site and condition-specific roles for MBL in the pathogenesis of Aspergillus disease. In a model of invasive pulmonary aspergillosis, a single dose of $0.05 \mathrm{mg} / \mathrm{kg}$ of recombinant human MBL increased mouse survival from 0 to 80\% [125]. MBL-mediated protection was associated with increased splenocyte production of TNF $\alpha$ and IL-1 $\beta$, and decreased IL-10 production [125]. In contrast, during intravenous A. fumigatus infection, MBL-deficient mice were more resistant to fungal challenge [126]. In a model of $A$. fumigatus-induced asthma, MBL-deficient mice exhibited significantly lower production of type- 2 cytokines and reduced airway hyperresponsiveness at 4 days post challenge, suggesting that MBL contributes to the allergic response towards Aspergillus [127]. However, by 28 days post challenge, minimal differences were observed between wild type and MBL-deficient mice [127], suggesting that MBL is not involved in the airway remodeling seen in chronic fungal asthma. In humans, polymorphisms resulting in reduced MBL expression have been associated with chronic necrotizing pulmonary aspergillosis [128]. Taken together, these findings suggest that MBL-mediated recognition of A. fumigatus mannans is likely important during early pulmonary host-fungal interactions.

While the mannan core of GM is not recognized by sera from aspergillosis patients [110], the oligogalactofuranose side chains of GM are antigenic in experimental animals [129]. An anti-galactofuranose monoclonal antibody forms the basis for the non-culture based Aspergillus antigen EIA, which has revolutionized the early diagnosis of invasive aspergillosis in immunocompromised patients [130,131]. No host receptors specific for A. fumigatus oligogalactofuranose have been described to date. 


\subsection{Alpha-Glucan}

The $\alpha$-(1,3)-glucan of A. fumigatus is found within the outer cell wall during growth in vitro, where it is involved in cell wall stability and agglutination of germinating conidia and hyphae [132-134]. However, the role of $\alpha$-glucan in mediating aggregation may vary by morphology and environment, as electron microscopy studies of hyphae during pulmonary infection localized $\alpha$-glucan largely within the inner cell wall of hyphae [135].

No host receptor for $\alpha$-glucan has yet been identified, however, this polysaccharide is thought to play both direct and indirect roles in the immune response against A. fumigatus. Purified $\alpha$-glucan inhibits both TLR2 and TLR4-mediated IL-6 production by PBMCs, although the molecular mechanisms underlying this observation remain unclear [136]. A. fumigatus mutants deficient in $\alpha$-glucan produce conidia in which the normally-inert rodlet layer is covered by an amorphous layer of glycoproteins [137]. During germination, these conidia display increased amounts of surface exposed $\beta$-glucan and chitin [137], are more readily phagocytosed and killed by mouse alveolar macrophages, and induce higher levels of TNF $\alpha$ secretion by these cells in vitro [137]. Mutants lacking $\alpha$-glucan are hypovirulent in mouse models of invasive aspergillosis, where conidia fail to germinate into hyphae [137], likely as a consequence of the dramatic alterations in cell wall structure. Collectively, these findings suggest that $\alpha$-glucan plays an important role in masking cell wall PAMPs from immune recognition during early germination.

Although natural antibodies to $\alpha$-glucan have not been described, a synthetic $\alpha$-(1,3)-glucan pentasaccharide has been used successfully to generate anti- $\alpha$-glucan antibodies [138]. These antibodies recognized native $\alpha$-glucan on the surface of germinating A. fumigatus conidia, however, their potential as diagnostic tools and the ability of vaccination with this pentasaccharide or administration of anti- $\alpha$-glucan antibodies to protect against $A$. fumigatus infection have yet to be evaluated.

\subsection{Chitin}

Chitin is located within the inner cell wall of A. fumigatus and plays an important role in structural integrity of the fungal cell. No host cell receptor for A. fumigatus chitin has been identified to date, however, the interaction of this glycan with a number of soluble factors has been implicated in the modulation of inflammation.

M-ficolin interacts with chitin on the surface of A. fumigatus young hyphae, and results in cleavage of the complement protein C4 by the protease MASP-2 [108]. Incubating A549 airway epithelial cells with M-ficolin and A. fumigatus extract resulted in elevated IL-8 production by these cells [108], suggesting that recognition of chitin by M-ficolin may alter inflammatory responses. Other members of the ficolin family H-ficolin (also known as ficolin-3), L-ficolin (also known as ficolin-2), and its murine ortholog A-ficolin have also been reported to recognize A. fumigatus conidia [139-141]. While the specific fungal ligands bound by these ficolins have not been defined, $\mathrm{N}$-acetylglucosamine inhibits the binding of these soluble factors to A. fumigatus, suggesting that they may recognize chitin [139-141]. As with $\mathrm{M}$-ficolin, treatment with $\mathrm{H}$ - and L-ficolin increased A. fumigatus conidia binding to A549 airway epithelial cells, and enhanced the release of IL-8 [141,142]. Intriguingly, both A- and L-ficolin treatment decreased the amount of IL- $1 \beta$, IL-6, IL-8, and TNF $\alpha$ released by human monocyte-derived macrophages and neutrophils in response to conidia, despite increased levels of fungal uptake and killing [142]. H-ficolin enhanced activation of the lectin-dependent complement cascade in vitro, leading to increased deposition of C3 onto the conidial surface [141]. Studies using transgenic mice deficient in specific ficolins would greatly improve our understanding of the role of these proteins in the pathogenesis of $A$. fumigatus infection.

Purified A. fumigatus chitin has been reported to induce anti-inflammatory effects via induction of IL-1Ra production by human PBMCs [143]. IL-1Ra production was mediated by anti-chitin IgG antibodies found in normal human serum interacting with Fc $\gamma$ RII, leading to phagocytosis of chitin particles [143]. Interestingly, in the presence of TLR-2, -4 , or NOD2 ligands, this response could be 
re-programmed to augment release of pro-inflammatory IL-1 $\beta$ [143]. Thus, the immune consequences of host-chitin interactions are likely context specific, and may vary during different stages of infection.

In animal models of fungal allergy, chitin exacerbates detrimental type-2 responses. Repeated exposure of mice to A. fumigatus conidia, or commercial crab shell chitin alone, was unable to induce a significant adaptive $\mathrm{T}_{\mathrm{H}} 2$ cell response, however, a combination of the two resulted in increased type-2 cytokines, such as IL-4, IL-5, and IL-13, eosinophilia, and high IgE antibody titers [63]. This phenomenon was initiated by $\mathrm{C} 3$ protein cleavage to generate $\mathrm{C} 3 \mathrm{a}$ via the alternative pathway of the complement cascade, leading to a suppression of regulatory dendritic and $\mathrm{T}$ cells, and induction of allergy-promoting $\mathrm{T}_{\mathrm{H}} 2$ cells [63]. Similar findings were reported using purified crab shell chitin as an adjuvant when administering $A$. fumigatus culture filtrate intraperitoneally to mice [144]. Although priming with chitin prior to challenge reduced the release of IL-4, -5 , and -13 in response to culture filtrate challenge, chitin priming still enhanced both eosinophil recruitment and the secretion of IgE antibodies [144]. Similarly, mice receiving repeated intranasal inoculation of conidia of an A. fumigatus strain with increased levels of exposed chitin resulted in enhanced eosinophil recruitment to the lungs, as compared to those exposed to the wild type strain Af293 [145]. The resulting T-helper cells were skewed to a type-2 phenotype, producing less IFN- $\gamma$, and more IL-4 [145]. This heightened type-2 response was detrimental to the host, as eosinophil-deficient, sensitized mice had significantly greater survival in a neutropenic model of $A$. fumigatus infection, as compared with wild type sensitized mice [145]. Taken together, these studies suggest that chitin elicits a predominantly type- 2 immune response, although the host receptors involved in mediating this response remain undefined.

\subsection{Galactosaminogalactan}

Galactosaminogalactan (GAG) is a linear heteropolysaccharide composed of $\alpha$-(1,4)-linked galactose and $N$-acetylgalactosamine (GalNAc) $[146,147]$ that is found in the outer cell wall and extracellular matrix of hyphae [132]. Partial N-deacetylation of GalNAc residues renders the polymer cationic, and allows GAG to mediate adherence to the hyphal cell wall, as well as other anionic surfaces, such as human cells, plastic, and glass [101,148].

GAG has been described to play a number of passive and active roles in counteracting host immune responses. GAG conceals more immunoreactive cell wall components, such as $\beta$-glucan from host detection [101]. The cationic nature of GAG also protects the hyphae from neutrophil-mediated killing by repelling the cationic peptides found in neutrophil extracellular traps [149]. GAG also plays an active role in altering immune responses to A. fumigatus. A purified fraction of GAG was found to induce apoptosis of human neutrophils in whole blood samples [147], a process mediated by natural killer (NK) cells [150]. Soluble GAG induced neutrophil ROS production through an unknown mechanism, which in turn increased expression of MHC class I chain-related molecule A (MIC-A) on the surface of neutrophils [150]. MIC-A binding to NKG2D on the surface of the NK cells was then linked to Fas-dependent apoptosis via the caspase-8 pathway [150]. Purified GAG can also stimulate IL-1Ra secretion by human PBMCs, resulting in a suppression of $\mathrm{T}_{\mathrm{H}} 1$ and $\mathrm{T}_{\mathrm{H}} 17$ responses [151]. Finally, GAG has been reported to bind and activate human platelets, resulting in degranulation and exposure of CD62P on their surface [152]. The mechanism of these GAG-dependent direct effects on immune cells and the host receptors involved in GAG recognition are largely unknown.

As with other exopolysaccharides, GAG is antigenic in humans. Anti-GAG antibodies are present in up to $40 \%$ of human sera samples, even in the absence of prior history of Aspergillus disease [147]. Importantly, however, many of these antibodies also reacted with glycoproteins of Campylobacter jejuni, suggesting that the antibodies may have developed in response to other microbial glycans with structural similarity to GAG. This hypothesis, that GAG shares similarities with bacterial exopolysaccharides, is supported by a recent study demonstrating cross-species activity of bacterial glycoside hydrolases from Pseudomonas aeruginosa against $A$. fumigatus GAG [153]. 


\subsection{Non-fumigatus Aspergillus Species}

While A. fumigatus represents roughly $80 \%$ of all Aspergillus-related infections, it is not the most abundant species isolated from environmental sampling, suggesting that it expresses unique virulence factors to enable it to cause human infection. Aspergillus nidulans, while commonly isolated from the environment, is rarely associated with infections, except in patients with NADPH oxidase deficiency (chronic granulomatous disease, CGD). Although the reasons underlying this observation are not fully understood, it has been suggested that differences in cell wall GAG production may contribute to the pathogenicity of $A$. nidulans in patients with CGD. A. nidulans produces low levels of cell wall GAG due to reduced expression of the glucose 4-epimerase UgeB that synthesizes $N$-acetylgalactosamine, and as a result, is more sensitive to killing by neutrophil extracellular traps (NETs) [149]. Patients with CGD are unable to form NETs, and are thus lacking a key element of host defence against this pathogen. Low levels of cell wall associated GAG in A. nidulans have also been linked to increased production of pro-inflammatory cytokines by CGD PBMCs [154].

Aspergillus terreus is another uncommon cause of invasive aspergillosis [155]. Conidia of A. terreus display higher levels of $\beta$-glucan and galactomannan then do those of A. fumigatus [156]. Conidia of A. terreus were more rapidly phagocytosed by murine alveolar macrophages than those of A. fumigatus, and this was dependent on dectin-1 and mannose receptors [156]. Interestingly, unlike A. fumigatus, conidia of $A$. terreus failed to germinate within the phagolysosome, and persisted in a dormant but viable state, without inducing macrophage injury [156]. Another unique feature of $A$. terreus is its capacity to produce accessory conidia, in addition to those formed by phialides, both in vitro as well as in vivo. These accessory conidia are physically distinct, and exhibit higher levels of exposed $\beta$-glucan, resulting in increased detin- 1 dependent production of pro-inflammatory cytokines by murine alveolar macrophages, in vitro and in vivo [157].

\section{Cryptococcus neoformans}

Infection with the yeast Cryptococcus neoformans is acquired by inhalation of dessicated yeast cells or basidiospores from fungi that are ubiquitous in the environment [158]. This exposure usually results in limited asymptomatic pulmonary infection; however, immunocompromised patients are at risk of developing pneumonia, disseminated disease, and meningitis. During infection, C. neoformans produces a large, mucoid capsule that surrounds and protects the yeast cells and is shed in large amounts during growth. The capsule is composed of three major components: glucuronoxylomannan, galactoxylomannan, and mannoproteins [159] that play key roles in the pathogenesis of cryptococcosis, by interfering with host recognition of $\beta$-glucans and mannoproteins within the cell wall [160], and cell phagocytosis, as well as by facilitating intracellular survival, replication, and extrusion through complex immunosuppressive and immunomodulatory mechanisms [161-163].

\subsection{Glucuronoxylomannan}

Glucuronoxylomannan (GXM) is the outermost and most abundant component of the capsule, forming $>90 \%$ of its mass. GXM is composed of a poly- $\alpha-(1,3)$-mannose backbone that can be 6-O acetylated, and substituted with $\beta$-(1,2)-linked glucuronic acid sidechains, and $\beta-(1,2)$ - or $\beta$-(1,4)-linked xylose sidechains, depending on the serotype [158]. While the full repertoire of host receptors for this glycan remain poorly defined, several studies have suggested that GXM plays an important role in host-fungal interactions (reviewed in [164]). GXM is recognized by CD14, CD18, TLR2, and TLR4 in vitro; however, none of these pattern recognition receptors was absolutely required for serum clearance or hepatosplenic polysaccharide accumulation in vivo [165]. Knockout mouse models have shown a modest role for TLR2 or CD14, but not TLR4, on survival after cryptococcal infection [166]. Notably, deletion of the intracellular protein MyD88 had a much more significant effect on survival, fungal burden, and GXM levels in the lungs and sera after intranasal infection, suggesting that additional innate immune receptors that signal via this adaptor mediate the host 
response to GXM [166]. GXM can also directly interact with Fc $\gamma$ RIIB, which has been implicated in $C$. neoformans uptake by phagocytic cells $[167,168]$; however, this interaction produces inhibitory signals that contribute to immune unresponsiveness [169].

Invasion and lysis of A549 airway epithelial cells by C. neoformans can be inhibited by anti-GXM antibodies [170]. Studies of leukocyte interactions with purified GXM in vitro have also reported a variety of host responses to this glycan. These include the production of TNF $\alpha$, IL-6, IL-10, and RANTES by murine peritoneal macrophages [171], and induction of TGF $\beta$, iNOS, and nitric oxide, leading to autophagy and ultimately apoptosis in RAW 264.7 macrophages [172]. Rat peritoneal macrophages also produce iNOS and undergo nitric oxide-dependent apoptosis in response to GXM [173]. Macrophage apoptosis was also dependent on CD18, Fc $\gamma$ RII, and protein kinase $\mathrm{C}$ activation, but was associated with down-regulation of caspase-3 activity, suggesting that GXM-mediated apoptosis was mediated through a caspase-independent pathway [173]. GXM was reported to bind to CD18 on human neutrophils, raising the possibility that GXM may activate the $\beta 2$-integrin apoptosis pathway, although apoptosis was not directly studied in this report [173].

In vitro studies also suggest that GXM can influence the adaptive immune response through inhibition of CD4 T cell activation [174]. Internalization of GXM by mouse BMDCs reduced their ability to induce antigen-specific T cell proliferation and IL-2 release [175]. Although this phenomenon was independent of cell death, a second study reported that GXM internalization by human monocyte-derived macrophages led to the Fas-mediated apoptosis of T cells [176]. GXM treatment also directly reduced $\mathrm{T}$ cell proliferation in response to PMA/ionomycin and anti-CD3 antibodies [177].

In addition to these direct effects on the immune response, GXM may also conceal ligands deeper in the capsule and cell wall from immune detection [160]. C. neoformans mutants lacking GXM induced higher levels of pro-inflammatory cytokines IL-12p40 and TNF $\alpha$ production by dendritic cells, than did wild type fungi [175].

C. neoformans strains deficient in GXM xylosylation are severely attenuated in virulence in a murine intravenous infection model [178], while strains deficient in GXM O-acetylation exhibit heightened virulence [179]; however, neither of these studies reported on the immune response mounted against these strains. Studies reporting the effects of purified GXM on immune responses in vivo have validated some of the in vitro observations discussed above. Intraperitoneal injection of purified GXM resulted in uptake by peritoneal macrophages and nitric oxide production in rats [173], as well as increased Fas/FasL-dependent peritoneal macrophage apoptosis in mice [172]. Intrapulmonary administration of GXM led to upregulation of pulmonary iNOS in rats [173], and induced IL-10 and TNF $\alpha$ secretion in mice [171]. Co-administration of GXM with chitin elicited higher levels of IL-10, IL-17, and TNF $\alpha$ release, than either glycan alone [180]. Thus, it is possible that this synergistic response to multiple glycans enhances the specificity of the immune response to fungal pathogens, while avoiding deleterious responses to environmental glycans.

\subsection{Galactoxylomannan}

A second important polysaccharide found within the $C$. neoformans capsule is galactoxylomannan (GalXM), composed of an $\alpha-(1,6)$-galactose backbone with trisaccharide branches of mannose- $\alpha-(1,3)$ mannose- $\alpha-(1,4)$-galactose- $\beta-(1,3)[158]$. These branches may be further xylosylated through $\beta-(1,2)$ and $\beta-(1,3)$ linkages [158]. GalXM is located deep within the capsule, adjacent to the cell wall, and forms $5-10 \%$ of its mass [159].

As with GXM, the effects of purified GalXM on leukocyte responses have also been studied. GalXM binds CD18 on human neutrophils [181], and induces TGF $\beta$, TNF $\alpha$ and iNOS production by RAW macrophages, leading to autophagy and apoptosis mediated by Fas/FasL interactions [172]. GalXM has a more marked effect on the cells of the adaptive immune system, as compared to GXM. Purified GalXM induces the release of IFN- $\gamma$ and IL-10 [182] by human PBMCs, suppresses purified human $\mathrm{T}$ lymphocyte proliferation, and directly induces Fas/FasL-dependent $\mathrm{T}$ cell apoptosis. GalXM-induced apoptosis of human T cells is dependent on interactions with CD7 and CD43 
(also known as leukosialin or sialophorin) that activate both extrinsic and intrinsic apoptosis pathways through caspase-8 cleavage [183,184]. As with GXM, peritoneal injection of GalXM also increases Fas/FasL-dependent apoptosis of resident macrophages [172]. Administration of GalXM, in this model, was associated with reduced inflammatory cytokine expression by splenocytes, and caspase- and Fas-dependent apoptosis of antigen-specific B cells, resulting in a state of immune paralysis [185]. While virulence studies using GalXM-deficient $C$. neoformans have revealed these strains to be hypovirulent in vivo [186], detailed studies of the GalXM-specific immune response have yet to be performed.

\subsection{Mannoproteins}

Mannoproteins comprise a small fraction $(<1 \%)$ of the C. neoformans capsule. Mannosylation of these proteins is extensive, such that mannose residues comprise $80-90 \%$ of the weight of these molecules [187], and is required for mannoprotein-mediated $\mathrm{T}$ cell stimulation [188]. Like GalXM, mannoproteins are situated deep within the capsule, which conceals them from immune recognition $[159,189]$.

Unlike GalXM and GXM that have complex immunosuppressive and immunomodulatory effects, mannoproteins appear to induce a predominately pro-inflammatory immune response [190]. In studies using purified capsule components, mannoproteins were found to be the strongest inducers of human PBMC proliferation [191] and IL-6 production [192]. Proliferation of PBMCs in response to mannoproteins could be inhibited by antibodies against ICAM-1, LFA-1, and MHC class II, suggesting that this response is dependent on antigen recognition [191]. Human dendritic cells have been found to internalize and process mannoproteins via the mannose receptor, leading to the maturation and activation of these cells [193]. Mannoprotein-activated dendritic cells produced IL-12 and TNF $\alpha$, and were efficient at stimulating CD8 and CD4 T cell proliferation, and T cell differentiation towards a $\mathrm{T}_{\mathrm{H}} 1$ phenotype [194]. Mice lacking the mannose receptor died significantly faster than wild type mice, with higher lung fungal burdens at 4 weeks after infection, and they displayed impaired $\mathrm{CD}^{+} \mathrm{T}$ cell responses to mannoprotein [195]. Mannoprotein-dependent $\mathrm{T}_{\mathrm{H}} 1$ responses also provided cross-fungal immunity against lethal C. albicans challenge [196]. Thus, although mannoproteins are highly effective at inducing protective antifungal immune responses, their abundance and location deep within the capsule likely limits their role as activators of protective antifungal immune responses.

\subsection{Cryptococcus gattii}

While C. neoformans typically only causes disease in immunosuppressed individuals, such as AIDS patients, a recently emerged strain of Cryptococcus gattii isolated from the Pacific Northwest has been reported to infect and cause disease in immunocompetent hosts [197]. Studies of the differences in virulence, that could contribute to this difference in host requirement, found that this strain of C. gattii induced a much lower inflammatory response, as compared with C. neoformans [198-200]. Immunocompetent mice infected with $C$. gattii exhibited limited cellular recruitment to the site of infection, and depletion of CD4-positive cells had no effect on survival, while mice infected with C. neoformans displayed a robust cellular immune response, and CD4 cell depletion significantly reduced survival time [200]. Coincubation of the two Cryptococcus strains with dendritic cells, in vitro, found that while C. neoformans stimulated a strong IL-6 response, C. gattii failed to induce IL-6 production by these cells [200]. This difference in cytokine response was related to partial deacetylation of C. gattii GXM, that was absent in C. neoformans. Chemical deacetylation of GXM from both species abolished their recognition by dendritic cells [200]. The mechanism underlying this deacetylation-dependent difference in host response is unknown, though it is interesting to hypothesize that there are similarities between this process and the role of partially deacetylated A. fumigatus GAG in immune evasion. Complement protein $\mathrm{C} 3$ also binds more strongly to GXM of $C$. neoformans than C. gattii, although this difference in C3 binding was attributed to differences in polysaccharide branching, rather than deacetylation [201]. 


\section{Histoplasma capsulatum}

Histoplasma capsulatum is a thermally dimorphic fungus that is a primary human pathogen [202]. $H$. capsulatum grows in a filamentous form in the environment, where it produces conidia that can be disseminated, particularly during excavation or other physical disruption [203]. Following inhalation, and exposure to higher body temperatures, conidia develop into their yeast form, causing pulmonary and disseminated infection [202]. Studies of immune interactions with $H$. capsulatum have been largely limited to elucidating the strategies by which this organism conceals $\beta$-glucans.

\section{Alpha-(1,3)-Glucan}

As with $A$. fumigatus, $\alpha-(1,3)$-glucan is found in the outer cell wall of $H$. capsulatum, where it can mask $\beta$-glucans from detection by dectin-1. Strains deficient in $\alpha$-glucan were significantly attenuated in their ability to kill murine P388D1 macrophage-like cells in co-culture [204], and were rapidly phagocytosed by these cells, leading to increased dectin-1-dependent TNF $\alpha$ secretion [205]. Interestingly, $\alpha$-glucan-deficient strains of $H$. capsulatum and wild type $C$. albicans induced similar levels of TNF $\alpha$ production [205], suggesting that the efficiency of $\beta$-glucan masking by H. capsulatum may contribute to the success of this organisms as a primary pathogen. Masking of $\beta$-glucans by $\alpha$-glucan is not universal among strains of $H$. capsulatum, as $\alpha$-glucan-deficient strains (chemotype I), have been reported [206]. Although these yeast bind dectin- 1 during log phase growth, dectin-1 binding is lost during stationary phase [206]. While the effects of deleting $\alpha$-glucan synthase in chemotype I strains on stationary phase masking of $\beta$-glucans has not been studied, inhibition of $\alpha$-glucan synthase function via RNA interference resulted in no decrease in virulence, either in vitro or in vivo [206]. These findings suggest that $\beta$-glucan-masking in chemotype I strains is $\alpha$-glucan independent [206,207]. Despite the absence of $\alpha$-glucan, chemotype I yeast retain their ability to be internalized by, and kill, mouse macrophages [206], although less rapidly than $\alpha$-glucan-sufficient strains [208].

In addition to $\alpha$-glucan masking of $\beta$-glucans from immune recognition, $H$. capsulatum also secretes $\beta$-glucanase enzymes to further limit surface exposure of this glycan $[207,209]$. Strains from both chemotypes that are deficient in $\beta$-glucanase exhibit increased recognition by dectin-1, resulting in greater amounts of TNF $\alpha$ and IL- 6 release by murine peritoneal macrophages during infection $[207,209]$. In $\alpha$-glucan sufficient strains, deletion of $\alpha$-glucan synthase resulted in a greater increase in dectin- 1 binding than did deletion of $\beta$-glucanase, although the effects were additive [207]. These observations suggest that while the masking of $\beta$-glucan with the $\alpha$-glucan layer is the dominant mechanism of immune evasion, the two strategies are complementary. It has been suggested that the role of the secreted $\beta$-glucanase is to "trim" off any exterior $\beta$-glucan that remains exposed beyond the $\alpha$-glucan coat surrounding the yeast cell [207].

Studies in mouse models have mirrored these in vitro findings. Chemotype II H. capsulatum strains deficient in $\alpha$-glucan were significantly attenuated in virulence and exhibited reduced ability to disseminate beyond the lung in a mouse model of pulmonary infection [206]. In contrast, naturally $\alpha$-glucan-deficient chemotype I strains remained virulent in mouse models of pulmonary histoplasmosis, and deletion of $\alpha$-glucan synthase in these strains had no effects on overall virulence [206]. Although both chemotypes of H. capsulatum are capable of causing lethal diseases, studies using a sub-lethal pulmonary infection mouse model revealed differences in the immune response to these two strain types. Infection with $\alpha$-glucan-deficient chemotype I $H$. capsulatum was associated with greater pulmonary levels of IFN- $\gamma$, IL-1 $\beta$, IL-12, and TNF $\alpha$, in association with increased weight loss, more severe pathology in lung histology, and higher pulmonary fungal burden later in the infection [208]. These differences in the kinetics of infection further support the hypothesis that chemotype I strains utilize unique virulence factors to support infection. Studies in mice have also confirmed the importance of the $\beta$-glucanase in virulence [207]. Mice infected intranasally with $\beta$-glucanase-deficient $H$. capsulatum strains had significantly lower pulmonary fungal burden than mice infected with the wild type parent strain, regardless of chemotype [207]. This difference in fungal 
burden was not observed in dectin-1-deficient mice, confirming that these alterations in virulence were due to differences in $\beta$-glucan recognition [207].

\section{Thoughts and Perspectives}

Significant progress has been made in recent years regarding the study of fungal exopolysaccharides and the effects they have on the host immune system. These findings have led to a range of new therapeutic strategies targeting fungal polysaccharides [210]. In addition to the currently licensed echinocandins, inhibitors of glycosyl phosphatidylinositol synthesis that prevent incorporation of mannoproteins into the fungal cell wall, are currently in clinical trials [211]. Other efforts include generating antibodies against $C$. albicans mannans [212], cell wall glycoproteins [213], and A. fumigatus $\alpha$-glucan [138], to test the vaccine potential of these cell wall components. Finally, we have recently reported the use of microbial glycoside hydrolases to degrade Aspergillus GAG, increase $\beta$-glucan exposure, and reduce virulence in a mouse model of invasive aspergillosis [153,214]. While many of these approaches remain in the early experimental phase, the therapeutic potential of the fungal cell wall is enormous.

Another promising avenue of research is to exploit immunomodulatory properties of fungal exopolysaccharides as treatments for inflammatory and autoimmune diseases. For example, A. fumigatus GAG has been proposed as a treatment for colitis through the induction of IL-1Ra [151]. Similarly, C. neoformans GalXM has been investigated as a treatment for rheumatoid arthritis, due to its ability to induce T cell apoptosis and inhibit IL-17 production [215].

Despite the tremendous advances in our understanding of the host immune response to fungal polysaccharides, significant challenges remain. Purification and characterization of cell wall polysaccharides remains in its infancy, and it is highly likely that variations in polymer length and post-synthetic modifications have a major impact on the host recognition and response to these molecules. Further, as evidenced by the results of studies using chitin and GXM [180], the immune response to combinations of polysaccharides may differ from those observed with isolated single polysaccharides. The study of fungal mutants that are deficient in specific polysaccharides is helpful, however, compensatory changes in cell wall composition through activation of the cell wall integrity and other pathways can lead to misleading results. Further, strain-, species-, and growth condition-dependent differences in cell wall composition may limit the generalizability of observations from in vitro and in vivo studies. Lastly, our ability to study the dynamics of cell wall polysaccharide synthesis and modification during infection remains in its infancy. A combination of experimental approaches, and the development of new tools to assay, manipulate, and quantify polysaccharide production in vitro and in vivo are required to move the field forward and maximize the therapeutic potential of these microbial molecules.

Acknowledgments: Brendan D. Snarr has been supported by graduate scholarships from Cystic Fibrosis Canada (CFC) and the Canadian Instituted of Health Research (CIHR). Work in the Salman T. Qureshi lab is supported by grants from the Research Institute of the McGill University Health Centre. Donald C. Sheppard is supported by a Research Chair from the Fonds de Recherche Quebec Santé.

Author Contributions: Brendan D. Snarr, Salman T. Qureshi, and Donald C. Sheppard wrote the manuscript.

Conflicts of Interest: The authors declare no conflict of interest. The founding sponsors had no role in the design of the study; in the collection, analyses, or interpretation of data; in the writing of the manuscript, and in the decision to publish the results.

\section{References}

1. Vallabhaneni, S.; Mody, R.K.; Walker, T.; Chiller, T. The Global Burden of Fungal Diseases. Infect. Dis. Clin. N. Am. 2016, 30, 1-11. [CrossRef] [PubMed]

2. Shoham, S.; Levitz, S.M. The immune response to fungal infections. Br. J. Haematol. 2005, 129, 569-582. [CrossRef] [PubMed]

3. Ramage, G.; Robertson, S.N.; Williams, C. Strength in numbers: Antifungal strategies against fungal biofilms. Int. J. Antimicrob. Agents 2014, 43, 114-120. [CrossRef] [PubMed] 
4. Tsui, C.; Kong, E.F.; Jabra-Rizk, M.A. Pathogenesis of Candida albicans biofilm. Pathog. Dis. 2016, 74, ftw018. [CrossRef] [PubMed]

5. Brown, G.D.; Gordon, S. Immune recognition of fungal $\beta$-glucans. Cell. Microbiol. 2005, 7, 471-479. [CrossRef] [PubMed]

6. Brown, G.D.; Taylor, P.R.; Reid, D.M.; Willment, J.A.; Williams, D.L.; Martinez-Pomares, L.; Wong, S.Y.C.; Gordon, S. Dectin-1 is a major $\beta$-glucan receptor on macrophages. J. Exp. Med. 2002, 196, 407-412. [CrossRef] [PubMed]

7. Brown, J.; O'Callaghan, C.A.; Marshall, A.S.J.; Gilbert, R.J.C.; Siebold, C.; Gordon, S.; Brown, G.D.; Jones, E.Y. Structure of the fungal $\beta$-glucan-binding immune receptor dectin-1: Implications for function. Protein Sci. 2007, 16, 1042-1052. [CrossRef]

8. Adams, E.L.; Rice, P.J.; Graves, B.; Ensley, H.E.; Yu, H.; Brown, G.D.; Gordon, S.; Monteiro, M.A.; Papp-Szabo, E.; Lowman, D.W.; et al. Differential High-Affinity Interaction of Dectin-1 with Natural or Synthetic Glucans Is Dependent upon Primary Structure and Is Influenced by Polymer Chain Length and Side-Chain Branching. J. Pharmacol. Exp. Ther. 2008, 325, 115-123. [CrossRef] [PubMed]

9. Latgé, J.-P. Tasting the fungal cell wall. Cell. Microbiol. 2010, 12, 863-872. [CrossRef] [PubMed]

10. Leal, S.M.; Cowden, S.; Hsia, Y.C.; Ghannoum, M.A.; Momany, M.; Pearlman, E. Distinct roles for Dectin-1 and TLR4 in the pathogenesis of Aspergillus fumigatus keratitis. PLoS Pathog. 2010, 6, e1000976. [CrossRef] [PubMed]

11. Dennehy, K.M.; Ferwerda, G.; Faro-Trindade, I.; Pyż, E.; Willment, J.A.; Taylor, P.R.; Kerrigan, A.; Tsoni, S.V.; Gordon, S.; Meyer-Wentrup, F.; et al. Syk kinase is required for collaborative cytokine production induced through Dectin-1 and Toll-like receptors. Eur. J. Immunol. 2008, 38, 500-506. [CrossRef]

12. Gringhuis, S.I.; Dunnen, D.J.; Litjens, M. Dectin-1 directs $\mathrm{T}$ helper cell differentiation by controlling noncanonical NF-kB activation through Raf-1 and Syk. Nature 2009, 10, 203-213. [CrossRef] [PubMed]

13. Khan, N.S.; Kasperkovitz, P.V.; Timmons, A.K.; Mansour, M.K.; Tam, J.M.; Seward, M.W.; Reedy, J.L.; Puranam, S.; Feliu, M.; Vyas, J.M. Dectin-1 Controls TLR9 Trafficking to Phagosomes Containing $\beta-1,3$ Glucan. J. Immunol. 2016, 196, 2249-2261. [CrossRef]

14. Tam, J.M.; Mansour, M.K.; Khan, N.S.; Seward, M.; Puranam, S.; Tanne, A.; Sokolovska, A.; Becker, C.E.; Acharya, M.; Baird, M.A.; et al. Dectin-1-Dependent LC3 Recruitment to Phagosomes Enhances Fungicidal Activity in Macrophages. J. Infect. Dis. 2014, 210, 1844-1854. [CrossRef] [PubMed]

15. Drummond, R.A.; Brown, G.D. The role of Dectin-1 in the host defence against fungal infections. Curr. Opin. Microbiol. 2011, 14, 392-399. [CrossRef] [PubMed]

16. Esteban, A.; Popp, M.W.; Vyas, V.K.; Strijbis, K.; Ploegh, H.L.; Fink, G.R. Fungal recognition is mediated by the association of dectin-1 and galectin-3 in macrophages. Proc. Natl. Acad. Sci. USA 2011, 108, 14270-14275. [CrossRef] [PubMed]

17. Dumic, J.; Dabelic, S.; Flögel, M. Galectin-3: An open-ended story. Biochim. Biophys. Acta (BBA) Gen. Subj. 2006, 1760, 616-635. [CrossRef] [PubMed]

18. Jouault, T.; El Abed-El Behi, M.; Martínez-Esparza, M.; Breuilh, L.; Trinel, P.-A.; Chamaillard, M.; Trottein, F.; Poulain, D. Specific recognition of Candida albicans by macrophages requires galectin-3 to discriminate Saccharomyces cerevisiae and needs association with TLR2 for signaling. J. Immunol. 2006, 177, 4679-4687. [CrossRef] [PubMed]

19. Wu, S.-Y.; Huang, J.-H.; Chen, W.-Y.; Chan, Y.-C.; Lin, C.-H.; Chen, Y.-C.; Liu, F.-T.; Wu-Hsieh, B.A. Cell Intrinsic Galectin-3 Attenuates Neutrophil ROS-Dependent Killing of Candida by Modulating CR3 Downstream Syk Activation. Front. Immunol. 2017, 8, 616. [CrossRef]

20. Linden, J.R.; De Paepe, M.E.; Laforce-Nesbitt, S.S.; Bliss, J.M. Galectin-3 plays an important role in protection against disseminated candidiasis. Med. Mycol. 2013, 51, 641-651. [CrossRef]

21. Rubin-Bejerano, I.; Abeijon, C.; Magnelli, P.; Grisafi, P.; Fink, G.R. Phagocytosis by human neutrophils is stimulated by a unique fungal cell wall component. Cell Host Microbe 2007, 2, 55-67. [CrossRef] [PubMed]

22. Li, X.; Utomo, A.; Cullere, X.; Choi, M.M.; Milner, D.A.; Venkatesh, D.; Yun, S.-H.; Mayadas, T.N. The $\beta$-glucan receptor Dectin-1 activates the integrin Mac-1 in neutrophils via Vav protein signaling to promote Candida albicans clearance. Cell Host Microbe 2011, 10, 603-615. [CrossRef] [PubMed] 
23. Ganesan, S.; Rathinam, V.A.K.; Bossaller, L.; Army, K.; Kaiser, W.J.; Mocarski, E.S.; Dillon, C.P.; Green, D.R.; Mayadas, T.N.; Levitz, S.M.; et al. Caspase-8 Modulates Dectin-1 and Complement Receptor 3-Driven IL-1 $\beta$ Production in Response to $\beta$-Glucans and the Fungal Pathogen, Candida albicans. J. Immunol. 2014, 193, 2519-2530. [CrossRef] [PubMed]

24. Smeekens, S.P.; Gresnigt, M.S.; Becker, K.L.; Cheng, S.-C.; Netea, S.A.; Jacobs, L.; Jansen, T.; van de Veerdonk, F.L.; Williams, D.L.; Joosten, L.A.B.; et al. An anti-inflammatory property of Candida albicans $\beta$-glucan: Induction of high levels of interleukin-1 receptor antagonist via a Dectin-1/CR3 independent mechanism. Cytokine 2015, 71, 215-222. [CrossRef] [PubMed]

25. Netea, M.G.; Gow, N.A.R.; Joosten, L.A.B.; Verschueren, I.; Van der Meer, J.W.M.; Kullberg, B.J. Variable recognition of Candida albicans strains by TLR4 and lectin recognition receptors. Med. Mycol. 2010, 48, 897-903. [CrossRef] [PubMed]

26. MacCallum, D.M.; Castillo, L.; Nather, K.; Munro, C.A.; Brown, A.J.P.; Gow, N.A.R.; Odds, F.C. Property Differences among the Four Major Candida albicans Strain Clades. Eukaryot. Cell 2009, 8, 373-387. [CrossRef] [PubMed]

27. Szabo, E.K.; MacCallum, D.M. A novel renal epithelial cell in vitro assay to assess Candida albicans virulence. Virulence 2014, 5, 286-296. [CrossRef] [PubMed]

28. Torosantucci, A.; Bromuro, C.; Chiani, P.; De Bernardis, F.; Berti, F.; Galli, C.; Norelli, F.; Bellucci, C.; Polonelli, L.; Costantino, P.; et al. A novel glyco-conjugate vaccine against fungal pathogens. J. Exp. Med. 2005, 202, 597-606. [CrossRef] [PubMed]

29. Torosantucci, A.; Chiani, P.; Bromuro, C.; De Bernardis, F. Protection by anti- $\beta$-glucan antibodies is associated with restricted $\beta-1,3$ glucan binding specificity and inhibition of fungal growth and adherence. PLoS ONE 2009, 4, e5392. [CrossRef] [PubMed]

30. Pietrella, D.; Rachini, A.; Torosantucci, A.; Chiani, P.; Brown, A.J.P.; Bistoni, F.; Costantino, P.; Mosci, P.; d'Enfert, C.; Rappuoli, R.; et al. A $\beta$-glucan-conjugate vaccine and anti- $\beta$-glucan antibodies are effective against murine vaginal candidiasis as assessed by a novel in vivo imaging technique. Vaccine 2010, 28, 1717-1725. [CrossRef] [PubMed]

31. Rachini, A.; Pietrella, D.; Lupo, P.; Torosantucci, A.; Chiani, P.; Bromuro, C.; Proietti, C.; Bistoni, F.; Cassone, A.; Vecchiarelli, A. An anti- $\beta$-glucan monoclonal antibody inhibits growth and capsule formation of Cryptococcus neoformans in vitro and exerts therapeutic, anticryptococcal activity in vivo. Infect. Immun. 2007, 75, 5085-5094. [CrossRef] [PubMed]

32. De Groot, P.W.J.; Kraneveld, E.A.; Yin, Q.Y.; Dekker, H.L.; Gross, U.; Crielaard, W.; de Koster, C.G.; Bader, O.; Klis, F.M.; Weig, M. The cell wall of the human pathogen Candida glabrata: Differential incorporation of novel adhesin-like wall proteins. Eukaryot. Cell 2008, 7, 1951-1964. [CrossRef] [PubMed]

33. Gow, N.A.; Hube, B. Importance of the Candida albicans cell wall during commensalism and infection. Curr. Opin. Microbiol. 2012, 15, 406-412. [CrossRef] [PubMed]

34. Shibata, N.; Suzuki, A.; Kobayashi, H.; Okawa, Y. Chemical structure of the cell-wall mannan of Candida albicans serotype A and its difference in yeast and hyphal forms. Biochem. J. 2007, 404, 365-372. [CrossRef] [PubMed]

35. Courjol, F.; Jouault, T.; Mille, C.; Hall, R.; Maes, E.; Sendid, B.; Mallet, J.M.; Guerardel, Y.; Gow, N.A.R.; Poulain, D.; et al. $\beta-1,2-$ Mannosyltransferases 1 and 3 Participate in Yeast and Hyphae $O$ - and $N$-Linked Mannosylation and Alter Candida albicans Fitness During Infection. Open Forum Infect. Dis. 2015, 2, ofv116. [CrossRef] [PubMed]

36. Ueno, K.; Okawara, A.; Yamagoe, S.; Naka, T.; Umeyama, T.; Utena-Abe, Y.; Tarumoto, N.; Niimi, M.; Ohno, H.; Doe, M.; et al. The mannan of Candida albicans lacking $\beta-1,2-$ linked oligomannosides increases the production of inflammatory cytokines by dendritic cells. Med. Mycol. 2013, 51, 385-395. [CrossRef]

37. Mora-Montes, H.M.; Bates, S.; Netea, M.G.; Castillo, L.; Brand, A.; Buurman, E.T.; Diaz-Jimenez, D.F.; Jan Kullberg, B.; Brown, A.J.P.; Odds, F.C.; et al. A Multifunctional Mannosyltransferase Family in Candida albicans Determines Cell Wall Mannan Structure and Host-Fungus Interactions. J. Biol. Chem. 2010, 285, 12087-12095. [CrossRef] [PubMed]

38. Zhang, S.Q.; Zou, Z.; Shen, H.; Shen, S.S.; Miao, Q.; Huang, X.; Liu, W.; Li, L.P.; Chen, S.M.; Yan, L.; et al. Mnn10 Maintains Pathogenicity in Candida albicans by Extending $\alpha-1,6-$ Mannose Backbone to Evade Host Dectin-1 Mediated Antifungal Immunity. PLoS Pathog. 2016, 12, e1005617. [CrossRef] [PubMed] 
39. Bain, J.M.; Louw, J.; Lewis, L.E.; Okai, B.; Walls, C.A.; Ballou, E.R.; Walker, L.A.; Reid, D.; Munro, C.A.; Brown, A.J.P.; et al. Candida albicans hypha formation and mannan masking of $\beta$-glucan inhibit macrophage phagosome maturation. mBio 2014, 5, e01874. [CrossRef] [PubMed]

40. Boxx, G.M.; Kozel, T.R.; Nishiya, C.T.; Zhang, M.X. Influence of Mannan and Glucan on Complement Activation and C3 Binding by Candida albicans. Infect. Immun. 2010, 78, 1250-1259. [CrossRef] [PubMed]

41. Cambi, A.; Netea, M.G.; Mora-Montes, H.M.; Gow, N.A.R.; Hato, S.V.; Lowman, D.W.; Kullberg, B.J.; Torensma, R.; Williams, D.L.; Figdor, C.G. Dendritic Cell Interaction with Candida albicans Critically Depends on N-Linked Mannan. J. Biol. Chem. 2008, 283, 20590-20599. [CrossRef]

42. Barreto-Bergter, E.; Figueiredo, R.T. Fungal glycans and the innate immune recognition. Front. Cell Infect. Microbiol. 2014, 4, 145. [CrossRef] [PubMed]

43. Appelmelk, B.J.; van Die, I.; van Vliet, S.J.; Vandenbroucke-Grauls, C.M.J.E.; Geijtenbeek, T.B.H.; van Kooyk, Y. Cutting Edge: Carbohydrate Profiling Identifies New Pathogens that Interact with Dendritic Cell-Specific ICAM-3-Grabbing Nonintegrin on Dendritic Cells. J. Immunol. 2003, 170, 1635-1639. [CrossRef] [PubMed]

44. Serrano-Gómez, D.; Sierra-Filardi, E.; Martínez-Nuñez, R.T.; Caparrós, E.; Delgado, R.; Muñoz-Fernández, M.A.; Abad, M.A.; Jiménez-Barbero, J.; Leal, M.; Corbí, A.L. Structural requirements for multimerization of the pathogen receptor dendritic cell-specific ICAM3-grabbing non-integrin (CD209) on the cell surface. J. Biol. Chem. 2008, 283, 3889-3903. [CrossRef] [PubMed]

45. Cambi, A.; Gijzen, K.; de Vries, L.J.M.; Torensma, R.; Joosten, B.; Adema, G.J.; Netea, M.G.; Kullberg, B.J.; Romani, L.; Figdor, C.G. The C-type lectin DC-SIGN (CD209) is an antigen-uptake receptor for Candida albicans on dendritic cells. Eur. J. Immunol. 2003, 33, 532-538. [CrossRef] [PubMed]

46. Netea, M.G.; Gow, N.A.R.; Munro, C.A.; Bates, S.; Collins, C.; Ferwerda, G.; Hobson, R.P.; Bertram, G.; Hughes, H.B.; Jansen, T.; et al. Immune sensing of Candida albicans requires cooperative recognition of mannans and glucans by lectin and Toll-like receptors. J. Clin. Investig. 2006, 116, 1642-1650. [CrossRef] [PubMed]

47. Vautier, S.; MacCallum, D.M.; Brown, G.D. C-type lectin receptors and cytokines in fungal immunity. Cytokine 2012, 58, 89-99. [CrossRef] [PubMed]

48. Graham, L.M.; Brown, G.D. The Dectin-2 family of C-type lectins in immunity and homeostasis. Cytokine 2009, 48, 148-155. [CrossRef] [PubMed]

49. Ifrim, D.C.; Quintin, J.; Courjol, F.; Verschueren, I.; van Krieken, J.H.; Koentgen, F.; Fradin, C.; Gow, N.A.R.; Joosten, L.A.B.; Van der Meer, J.W.M.; et al. The Role of Dectin-2 for Host Defense against Disseminated Candidiasis. J. Interferon Cytokine Res. 2016, 36, 267-276. [CrossRef] [PubMed]

50. Zhu, L.-L.; Zhao, X.-Q.; Jiang, C.; You, Y.; Chen, X.-P.; Jiang, Y.-Y.; Jia, X.-M.; Lin, X. C-Type Lectin Receptors Dectin-3 and Dectin-2 Form a Heterodimeric Pattern-Recognition Receptor for Host Defense against Fungal Infection. Immunity 2013, 39, 324-334. [CrossRef] [PubMed]

51. Miyake, Y.; Toyonaga, K.; Mori, D.; Kakuta, S.; Hoshino, Y.; Oyamada, A.; Yamada, H.; Ono, K.-I.; Suyama, M.; Iwakura, Y.; et al. C-type Lectin MCL Is an FcRg-Coupled Receptor that Mediates the Adjuvanticityof Mycobacterial Cord Factor. Immunity 2013, 38, 1050-1062. [CrossRef] [PubMed]

52. Sato, K.; Yang, X.-L.; Yudate, T.; Chung, J.-S.; Wu, J.; Luby-Phelps, K.; Kimberly, R.P.; Underhill, D.; Cruz, P.D.; Ariizumi, K. Dectin-2 is a pattern recognition receptor for fungi that couples with the Fc receptor gamma chain to induce innate immune responses. J. Biol. Chem. 2006, 281, 38854-38866. [CrossRef]

53. Ifrim, D.C.; Bain, J.M.; Reid, D.M.; Oosting, M.; Verschueren, I.; Gow, N.A.R.; van Krieken, J.H.; Brown, G.D.; Kullberg, B.J.; Joosten, L.A.B.; et al. Role of Dectin-2 for Host Defense against Systemic Infection with Candida glabrata. Infect. Immun. 2014, 82, 1064-1073. [CrossRef] [PubMed]

54. Kohatsu, L.; Hsu, D.K.; Jegalian, A.G.; Liu, F.-T.; Baum, L.G. Galectin-3 induces death of Candida species expressing specific $\beta-1,2-$ linked mannans. J. Immunol. 2006, 177, 4718-4726. [CrossRef] [PubMed]

55. Holmskov, U.; Malhotra, R.; Sim, R.B.; Jensenius, J.C. Collectins: Collagenous C-type lectins of the innate immune defense system. Immunol. Today 1994, 15, 67-74. [CrossRef]

56. Matsushita, M.; Fujita, T. Activation of the classical complement pathway by mannose-binding protein in association with a novel C1s-like serine protease. J. Exp. Med. 1992, 176, 1497-1502. [CrossRef] [PubMed]

57. Lillegard, J.B.; Sim, R.B.; Thorkildson, P.; Gates, M.A.; Kozel, T.R. Recognition of Candida albicans by mannan-binding lectin in vitro and in vivo. J. Infect. Dis. 2006, 193, 1589-1597. [CrossRef] [PubMed] 
58. Ip, W.-K.; Lau, Y.-L. Role of mannose-binding lectin in the innate defense against Candida albicans: Enhancement of complement activation, but lack of opsonic function, in phagocytosis by human dendritic cells. J. Infect. Dis. 2004, 190, 632-640. [CrossRef] [PubMed]

59. Van Asbeck, E.C.; Hoepelman, A.I.; Scharringa, J.; Herpers, B.L.; Verhoef, J. Mannose binding lectin plays a crucial role in innate immunity against yeast by enhanced complement activation and enhanced uptake of polymorphonuclear cells. BMC Microbiol. 2008, 8, 229. [CrossRef]

60. Ma, Y.J.; Doni, A.; Skjoedt, M.O.; Honore, C.; Arendrup, M.; Mantovani, A.; Garred, P. Heterocomplexes of Mannose-binding Lectin and the Pentraxins PTX3 or Serum Amyloid P Component Trigger Cross-activation of the Complement System. J. Biol. Chem. 2011, 286, 3405-3417. [CrossRef] [PubMed]

61. Nedovic, B.; Posteraro, B.; Leoncini, E.; Ruggeri, A.; Amore, R.; Sanguinetti, M.; Ricciardi, W.; Boccia, S. Mannose-Binding Lectin Codon 54 Gene Polymorphism and Vulvovaginal Candidiasis: A Systematic Review and Meta-Analysis. BioMed Res. Int. 2014, 2014, 1-7. [CrossRef] [PubMed]

62. Timpel, C.; Strahl-Bolsinger, S.; Ziegelbauer, K.; Ernst, J.F. Multiple functions of Pmt1p-mediated protein O-mannosylation in the fungal pathogen Candida albicans. J. Biol. Chem. 1998, 273, 20837-20846. [CrossRef] [PubMed]

63. Roy, R.M.; Paes, H.C.; Nanjappa, S.G.; Sorkness, R.; Gasper, D.; Sterkel, A.; Wuthrich, M.; Klein, B.S. Complement Component 3C3 and C3a Receptor Are Required in Chitin-Dependent Allergic Sensitization to Aspergillus fumigatus but Dispensable in Chitin-Induced Innate Allergic Inflammation. mBio 2013, 4, e00162-13. [CrossRef] [PubMed]

64. Mora-Montes, H.M.; Netea, M.G.; Ferwerda, G.; Lenardon, M.D.; Brown, G.D.; Mistry, A.R.; Kullberg, B.J.; O'Callaghan, C.A.; Sheth, C.C.; Odds, F.C.; et al. Recognition and Blocking of Innate Immunity Cells by Candida albicans Chitin. Infect. Immun. 2011, 79, 1961-1970. [CrossRef]

65. Hoang, A. Caspofungin acetate: An antifungal agent. Am. J. Health Syst. Pharm. 2001, 58, 1206-1214. [PubMed]

66. Van Dyken, S.J.; Mohapatra, A.; Nussbaum, J.C.; Molofsky, A.B.; Thornton, E.E.; Ziegler, S.F.; McKenzie, A.N.J.; Krummel, M.F.; Liang, H.-E.; Locksley, R.M. Chitin Activates Parallel Immune Modules that Direct Distinct Inflammatory Responses via Innate Lymphoid Type 2 and gd T Cells. Immunity 2014, 40, 414-424. [CrossRef] [PubMed]

67. Wagener, J.; Malireddi, R.K.S.; Lenardon, M.D.; Köberle, M.; Vautier, S.; MacCallum, D.M.; Biedermann, T.; Schaller, M.; Netea, M.G.; Kanneganti, T.-D.; et al. Fungal Chitin Dampens Inflammation through IL-10 Induction Mediated by NOD2 and TLR9 Activation. PLoS Pathog. 2014, 10, e1004050. [CrossRef] [PubMed]

68. Douglas, L.J. Candida biofilms and their role in infection. Trends Microbiol. 2003, 11, 30-36. [CrossRef]

69. Kumamoto, C.A.; Vinces, M.D. Alternative Candida albicans lifestyles: Growth on surfaces. Annu. Rev. Microbiol. 2005, 59, 113-133. [CrossRef] [PubMed]

70. Nett, J.E. The host's reply to Candida biofilm. Pathogens 2016, 5, 33. [CrossRef] [PubMed]

71. Chandra, J.; McCormick, T.S.; Imamura, Y.; Mukherjee, P.K.; Ghannoum, M.A. Interaction of Candida albicans with adherent human peripheral blood mononuclear cells increases $C$. albicans biofilm formation and results in differential expression of pro- and anti-inflammatory cytokines. Infect. Immun. 2007, 75, 2612-2620. [CrossRef] [PubMed]

72. Katragkou, A.; Kruhlak, M.J.; Simitsopoulou, M.; Chatzimoschou, A.; Taparkou, A.; Cotten, C.J.; Paliogianni, F.; Diza Mataftsi, E.; Tsantali, C.; Walsh, T.J.; et al. Interactions between human phagocytes and Candida albicans biofilms alone and in combination with antifungal agents. J. Infect. Dis. 2010, 201, 1941-1949. [CrossRef] [PubMed]

73. Katragkou, A.; Simitsopoulou, M.; Chatzimoschou, A.; Georgiadou, E.; Walsh, T.J.; Roilides, E. Effects of interferon- $\gamma$ and granulocyte colony-stimulating factor on antifungal activity of human polymorphonuclear neutrophils against Candida albicans grown as biofilms or planktonic cells. Cytokine 2011, 55, 330-334. [CrossRef]

74. Xie, Z.; Thompson, A.; Sobue, T.; Kashleva, H.; Xu, H.; Vasilakos, J.; Dongari-Bagtzoglou, A. Candida albicans biofilms do not trigger reactive oxygen species and evade neutrophil killing. J. Infect. Dis. 2012, 206, 1936-1945. [CrossRef] [PubMed]

75. Dwivedi, P.; Thompson, A.; Xie, Z.; Kashleva, H.; Ganguly, S.; Mitchell, A.P.; Dongari-Bagtzoglou, A. Role of Bcr1-activated genes Hwp1 and Hyr1 in Candida albicans oral mucosal biofilms and neutrophil evasion. PLoS ONE 2011, 6, e16218. [CrossRef] [PubMed] 
76. Yano, J.; Palmer, G.E.; Eberle, K.E.; Peters, B.M.; Vogl, T.; McKenzie, A.N.; Fidel, P.L. Vaginal epithelial cell-derived S100 alarmins induced by Candida albicans via pattern recognition receptor interactions are sufficient but not necessary for the acute neutrophil response during experimental vaginal candidiasis. Infect. Immun. 2014, 82, 783-792. [CrossRef] [PubMed]

77. Yano, J.; Lilly, E.; Barousse, M.; Fidel, P.L. Epithelial cell-derived S100 calcium-binding proteins as key mediators in the hallmark acute neutrophil response during Candida vaginitis. Infect. Immun. 2010, 78, 5126-5137. [CrossRef] [PubMed]

78. Nett, J.E.; Marchillo, K.; Spiegel, C.A.; Andes, D.R. Development and validation of an in vivo Candida albicans biofilm denture model. Infect. Immun. 2010, 78, 3650-3659. [CrossRef] [PubMed]

79. Wang, X.; Fries, B.C. A murine model for catheter-associated candiduria. J. Med. Microbiol. 2011, 60, 1523-1529. [CrossRef] [PubMed]

80. Nieminen, M.T.; Hernandez, M.; Novak-Frazer, L.; Kuula, H.; Ramage, G.; Bowyer, P.; Warn, P.; Sorsa, T.; Rautemaa, R. DL-2-hydroxyisocaproic acid attenuates inflammatory responses in a murine Candida albicans biofilm model. Clin. Vaccine Immunol. 2014, 21, 1240-1245. [CrossRef] [PubMed]

81. Conti, H.R.; Gaffen, S.L. IL-17-Mediated immunity to the opportunistic fungal pathogen Candida albicans. J. Immunol. 2015, 195, 780-788. [CrossRef] [PubMed]

82. Hebecker, B.; Naglik, J.R.; Hube, B.; Jacobsen, I.D. Pathogenicity mechanisms and host response during oral Candida albicans infections. Expert Rev. Anti Infect. Ther. 2014, 12, 867-879. [CrossRef] [PubMed]

83. Yano, J.; Noverr, M.C.; Fidel, P.L. Cytokines in the host response to Candida vaginitis: Identifying a role for non-classical immune mediators, S100 alarmins. Cytokine 2012, 58, 118-128. [CrossRef] [PubMed]

84. Montagna, M.T.; Lovero, G.; Borghi, E.; Amato, G.; Andreoni, S.; Campion, L.; Lo Cascio, G.; Lombardi, G.; Luzzaro, F.; Manso, E.; et al. Candidemia in intensive care unit: A nationwide prospective observational survey (GISIA-3 study) and review of the European literature from 2000 through 2013. Eur. Rev. Med. Pharmacol. Sci. 2014, 18, 661-674. [PubMed]

85. Kobayashi, H.; Mitobe, H.; Takahashi, K.; Yamamoto, T.; Shibata, N.; Suzuki, S. Structural study of a cell wall mannan-protein complex of the pathogenic yeast Candida glabrata IFO 0622 strain. Arch. Biochem. Biophys. 1992, 294, 662-669. [CrossRef]

86. Kobayashi, H.; Oyamada, H.; Iwadate, N.; Suzuki, H.; Mitobe, H.; Takahashi, K.; Shibata, N.; Suzuki, S.; Okawa, Y. Structural and immunochemical characterization of $\beta$-1,2-linked mannobiosyl phosphate residue in the cell wall mannan of Candida glabrata. Arch. Microbiol. 1998, 169, 188-194. [CrossRef] [PubMed]

87. West, L.; Lowman, D.W.; Mora-Montes, H.M.; Grubb, S.; Murdoch, C.; Thornhill, M.H.; Gow, N.A.R.; Williams, D.; Haynes, K. Differential virulence of Candida glabrata glycosylation mutants. J. Biol. Chem. 2013, 288, 22006-22018. [CrossRef] [PubMed]

88. Keppler-Ross, S.; Douglas, L.; Konopka, J.B.; Dean, N. Recognition of yeast by murine macrophages requires mannan but not glucan. Eukaryot. Cell 2010, 9, 1776-1787. [CrossRef] [PubMed]

89. Seider, K.; Gerwien, F.; Kasper, L.; Allert, S.; Brunke, S.; Jablonowski, N.; Schwarzmüller, T.; Barz, D.; Rupp, S.; Kuchler, K.; et al. Immune evasion, stress resistance, and efficient nutrient acquisition are crucial for intracellular survival of Candida glabrata within macrophages. Eukaryot. Cell 2014, 13, 170-183. [CrossRef] [PubMed]

90. Lima-Neto, R.G.; Beltrão, E.I.C.; Oliveira, P.C.; Neves, R.P. Adherence of Candida albicans and Candida parapsilosis to epithelial cells correlates with fungal cell surface carbohydrates. Mycoses 2011, 54, $23-29$. [CrossRef] [PubMed]

91. Pérez-García, L.A.; Csonka, K.; Flores-Carreón, A.; Estrada-Mata, E.; Mellado-Mojica, E.; Németh, T.; López-Ramírez, L.A.; Toth, R.; López, M.G.; Vizler, C.; et al. Role of Protein Glycosylation in Candida parapsilosis Cell Wall Integrity and Host Interaction. Front. Microbiol. 2016, 7, 306. [CrossRef] [PubMed]

92. Latge, J.P. Aspergillus fumigatus and aspergillosis. Clin. Microbiol. Rev. 1999, 12, 310-350. [PubMed]

93. Lee, M.J.; Sheppard, D.C. Recent advances in the understanding of the Aspergillus fumigatus cell wall. J. Microbiol. 2016, 54, 232-242. [CrossRef] [PubMed]

94. Filler, S.G.; Sheppard, D.C. Fungal Invasion of Normally Non-Phagocytic Host Cells. PLoS Pathog. 2006, 2, e129. [CrossRef] [PubMed]

95. Balloy, V.; Chignard, M. The innate immune response to Aspergillus fumigatus. Microbes Infect. 2009, 11, 919-927. [CrossRef] [PubMed] 
96. Dichtl, K.; Samantaray, S.; Aimanianda, V.; Zhu, Z.; Prevost, M.-C.; Latgé, J.-P.; Ebel, F.; Wagener, J. Aspergillus fumigatus devoid of cell wall $\beta-1,3$-glucan is viable, massively sheds galactomannan and is killed by septum formation inhibitors. Mol. Microbiol. 2014, 95, 458-471. [CrossRef] [PubMed]

97. Steele, C.; Rapaka, R.R.; Metz, A.; Pop, S.M.; Williams, D.L.; Gordon, S.; Kolls, J.K.; Brown, G.D. The $\beta$-Glucan Receptor Dectin-1 Recognizes Specific Morphologies of Aspergillus fumigatus. PLoS Pathog. 2005, 1, e42. [CrossRef] [PubMed]

98. Carrion, S.D.J.; Leal, S.M.; Ghannoum, M.A.; Aimanianda, V.; Latge, J.P.; Pearlman, E. The RodA Hydrophobin on Aspergillus fumigatus Spores Masks Dectin-1- and Dectin-2-Dependent Responses and Enhances Fungal Survival in vivo. J. Immunol. 2013, 191, 2581-2588. [CrossRef] [PubMed]

99. Werner, J.L.; Metz, A.E.; Horn, D.; Schoeb, T.R.; Hewitt, M.M.; Schwiebert, L.M.; Faro-Trindade, I.; Brown, G.D.; Steele, C. Requisite Role for the Dectin-1-Glucan Receptor in Pulmonary Defense against Aspergillus fumigatus. J. Immunol. 2009, 182, 4938-4946. [CrossRef] [PubMed]

100. Mezger, M.; Kneitz, S.; Wozniok, I.; Kurzai, O.; Einsele, H.; Loeffler, J. Proinflammatory Response of Immature Human Dendritic Cells is Mediated by Dectin-1 after Exposure to Aspergillus fumigatus Germ Tubes. J. Infect. Dis. 2008, 197, 924-931. [CrossRef] [PubMed]

101. Gravelat, F.N.; Beauvais, A.; Liu, H.; Lee, M.J.; Snarr, B.D.; Chen, D.; Xu, W.; Kravtsov, I.; Hoareau, C.M.Q.; Vanier, G.; et al. Aspergillus galactosaminogalactan mediates adherence to host constituents and conceals hyphal $\beta$-glucan from the immune system. PLoS Pathog. 2013, 9, e1003575. [CrossRef] [PubMed]

102. Werner, J.L.; Gessner, M.A.; Lilly, L.M.; Nelson, M.P.; Metz, A.E.; Horn, D.; Dunaway, C.W.; Deshane, J.; Chaplin, D.D.; Weaver, C.T.; et al. Neutrophils Produce Interleukin 17A (IL-17A) in a Dectin-1- and IL-23-Dependent Manner during Invasive Fungal Infection. Infect. Immun. 2011, 79, 3966-3977. [CrossRef] [PubMed]

103. Gessner, M.A.; Werner, J.L.; Lilly, L.M.; Nelson, M.P.; Metz, A.E.; Dunaway, C.W.; Chan, Y.R.; Ouyang, W.; Brown, G.D.; Weaver, C.T.; et al. Dectin-1-Dependent Interleukin-22 Contributes to Early Innate Lung Defense against Aspergillus fumigatus. Infect. Immun. 2011, 80, 410-417. [CrossRef] [PubMed]

104. Rivera, A.; Hohl, T.M.; Collins, N.; Leiner, I.; Gallegos, A.; Saijo, S.; Coward, J.W.; Iwakura, Y.; Pamer, E.G. Dectin-1 diversifies Aspergillus fumigatus-specific T cell responses by inhibiting T helper type 1 CD4 T cell differentiation. J. Exp. Med. 2011, 208, 369-381. [CrossRef] [PubMed]

105. Lilly, L.M.; Gessner, M.A.; Dunaway, C.W.; Metz, A.E.; Schwiebert, L.; Weaver, C.T.; Brown, G.D.; Steele, C. The $\beta$-Glucan Receptor Dectin-1 Promotes Lung Immunopathology during Fungal Allergy via IL-22. J. Immunol. 2012, 189, 3653-3660. [CrossRef] [PubMed]

106. Thomsen, T.; Schlosser, A.; Holmskov, U.; Sorensen, G.L. Ficolins and FIBCD1: Soluble and membrane bound pattern recognition molecules with acetyl group selectivity. Mol. Immunol. 2011, 48, 369-381. [CrossRef] [PubMed]

107. Fontaine, T.; Simenel, C.; Dubreucq, G.; Adam, O.; Delepierre, M.; Lemoine, J.; Vorgias, C.E.; Diaquin, M.; Latge, J.P. Molecular organization of the alkali-insoluble fraction of Aspergillus fumigatus cell wall. J. Biol. Chem. 2000, 275, 27594-27607. [CrossRef] [PubMed]

108. Jensen, K.; Lund, K.P.; Christensen, K.B.; Holm, A.T.; Dubey, L.K.; Moeller, J.B.; Jepsen, C.S.; Schlosser, A.; Galgóczy, L.; Thiel, S.; et al. M-ficolin is present in Aspergillus fumigatus infected lung and modulates epithelial cell immune responses elicited by fungal cell wall polysaccharides. Virulence 2017, 1-10. [CrossRef]

109. Ma, Y.J.; Doni, A.; Hummelshøj, T.; Honoré, C.; Bastone, A.; Mantovani, A.; Thielens, N.M.; Garred, P. Synergy between ficolin-2 and pentraxin 3 boosts innate immune recognition and complement deposition. J. Biol. Chem. 2009, 284, 28263-28275. [CrossRef] [PubMed]

110. Latge, J.P.; Kobayashi, H.; Debeaupuis, J.P. Chemical and immunological characterization of the extracellular galactomannan of Aspergillus fumigatus. Infect. Immun. 1994, 62, 5424-5433. [PubMed]

111. Leitao, E.A.; Bittencourt, V.C.B.; Haido, R.M.T.; Valente, A.P.; Peter-Katalinic, J.; Letzel, M.; de Souza, L.M.; Barreto-Bergter, E. $\beta$-galactofuranose-containing $O$-linked oligosaccharides present in the cell wall peptidogalactomannan of Aspergillus fumigatus contain immunodominant epitopes. Glycobiology 2003, 13, 681-692. [CrossRef] [PubMed]

112. Henry, C.; Fontaine, T.; Heddergott, C.; Robinet, P.; Aimanianda, V.; Beau, R.; Beauvais, A.; Mouyna, I.; Prevost, M.-C.; Fekkar, A.; et al. Biosynthesis of cell wall mannan in the conidium and the mycelium of Aspergillus fumigatus. Cell. Microbiol. 2016, 18, 1881-1891. [CrossRef] [PubMed] 
113. Paugam, A.; Sarfati, J.; Romieu, R.; Viguier, M.; Dupouy-Camet, J.; Latge, J.P. Detection of Aspergillus galactomannan: Comparison of an enzyme-linked immunoassay and a europium-linked time-resolved fluoroimmunoassay. J. Clin Microbiol. 1998, 36, 3079-3080.

114. Patterson, T.F.; Thompson, G.R., III; Denning, D.W.; Fishman, J.A.; Hadley, S.; Herbrecht, R.; Kontoyiannis, D.P.; Marr, K.A.; Morrison, V.A.; Nguyen, M.H.; et al. Practice Guidelines for the Diagnosis and Management of Aspergillosis: 2016 Update by the Infectious Diseases Society of America. Clin. Infect. Dis. 2016, 63, e1-e60. [PubMed]

115. Erwig, L.P.; Gow, N.A.R. Interactions of fungal pathogens with phagocytes. Nat. Rev. Microbiol. 2016, 14, 163-176. [CrossRef] [PubMed]

116. Serrano-Gómez, D.; Dominguez-Soto, A.; Ancochea, J.; Jimenez-Heffernan, J.A.; Leal, J.A.; Corbi, A.L. Dendritic Cell-Specific Intercellular Adhesion Molecule 3-Grabbing Nonintegrin Mediates Binding and Internalization of Aspergillus fumigatus Conidia by Dendritic Cells and Macrophages. J. Immunol. 2004, 173, 5635-5643. [CrossRef] [PubMed]

117. Serrano-Gómez, D.; Antonio Leal, J.; Corbí, A.L. DC-SIGN mediates the binding of Aspergillus fumigatus and keratinophylic fungi by human dendritic cells. Immunobiology 2005, 210, 175-183. [CrossRef] [PubMed]

118. Sun, H.; Xu, X.-Y.; Tian, X.-L.; Shao, H.-T.; Wu, X.-D.; Wang, Q.; Su, X.; Shi, Y. Activation of NF-kB and respiratory burst following Aspergillus fumigatus stimulation of macrophages. Immunobiology 2014, 219, 25-36. [CrossRef] [PubMed]

119. Loures, F.V.; Röhm, M.; Lee, C.K.; Santos, E.; Wang, J.P.; Specht, C.A.; Calich, V.L.G.; Urban, C.F.; Levitz, S.M. Recognition of Aspergillus fumigatus Hyphae by Human Plasmacytoid Dendritic Cells Is Mediated by Dectin-2 and Results in Formation of Extracellular Traps. PLoS Pathog. 2015, 11, e1004643. [CrossRef] [PubMed]

120. Taylor, P.R.; Roy, S.; Leal, S.M.; Sun, Y.; Howell, S.J.; Cobb, B.A.; Li, X.; Pearlman, E. Activation of neutrophils by autocrine IL-17A-IL-17RC interactions during fungal infection is regulated by IL-6, IL-23, ROR $\gamma \mathrm{t}$ and dectin-2. Nat. Immunol. 2014, 15, 143-151. [CrossRef] [PubMed]

121. Sun, H.; Xu, X.-Y.; Shao, H.-T.; Su, X.; Wu, X.-D.; Wang, Q.; Shi, Y. Dectin-2 is predominately macrophage restricted and exhibits conspicuous expression during Aspergillus fumigatus invasion in human lung. Cell. Immunol. 2013, 284, 60-67. [CrossRef] [PubMed]

122. Dumestre-Perard, C.; Lamy, B.; Aldebert, D.; Lemaire-Vieille, C.; Grillot, R.; Brion, J.P.; Gagnon, J.; Cesbron, J.Y. Aspergillus Conidia Activate the Complement by the Mannan-Binding Lectin C2 Bypass Mechanism. J. Immunol. 2008, 181, 7100-7105. [CrossRef] [PubMed]

123. Neth, O.; Jack, D.L.; Dodds, A.W.; Holzel, H. Mannose-binding lectin binds to a range of clinically relevant microorganisms and promotes complement deposition. Infect. Immun. 2000, 68, 688-693. [CrossRef] [PubMed]

124. Che, C.-Y.; Zhang, J.-F.; Lee, J.-E.; Lin, J.; Hu, L.-T.; Jiang, N.; Wang, Q.; Xu, Q.; Zhao, G.-Q. Early expression of mannose-binding lectin 2 during Aspergillus fumigatus infection in human corneal epithelial cells. Int. J. Ophthalmol. 2015, 8, 35-38. [PubMed]

125. Kaur, S.; Gupta, V.K.; Thiel, S.; Sarma, P.U.; Madan, T. Protective role of mannan-binding lectin in a murine model of invasive pulmonary aspergillosis. Clin. Exp. Immunol. 2007, 148, 382-389. [CrossRef] [PubMed]

126. Clemons, K.V.; Martinez, M.; Tong, A.-J.; Stevens, D.A. Immunology Letters. Immunol. Lett. 2010, 128, 105-107. [CrossRef] [PubMed]

127. Hogaboam, C.M. Mannose-binding lectin deficiency alters the development of fungal asthma: Effects on airway response, inflammation, and cytokine profile. J. Leukoc. Biol. 2003, 75, 805-814. [CrossRef] [PubMed]

128. Crosdale, D.J.; Poulton, K.V.; Ollier, W.E.; Thomson, W.; Denning, D.W. Mannose-binding lectin gene polymorphisms as a susceptibility factor for chronic necrotizing pulmonary aspergillosis. J. Infect. Dis. 2001, 184, 653-656. [CrossRef] [PubMed]

129. Stynen, D.; Sarfati, J.; Goris, A.; Prévost, M.C.; Lesourd, M.; Kamphuis, H.; Darras, V.; Latge, J.P. Rat monoclonal antibodies against Aspergillus galactomannan. Infect. Immun. 1992, 60, 2237-2245. [PubMed]

130. Luong, M.-L.; Filion, C.; Labbé, A.-C.; Roy, J.; Pépin, J.; Cadrin-Tourigny, J.; Carignan, S.; Sheppard, D.C.; Laverdiere, M. Clinical utility and prognostic value of bronchoalveolar lavagegalactomannan in patients with hematologic malignancies. Diagn. Microbiol. Infect. Dis. 2010, 68, 132-139. [CrossRef] [PubMed]

131. Lehrnbecher, T.; Robinson, P.D.; Fisher, B.T.; Castagnola, E.; Groll, A.H.; Steinbach, W.J.; Zaoutis, T.E.; Negeri, Z.F.; Beyene, J.; Phillips, B.; et al. Galactomannan, $\beta$-D-Glucan, and Polymerase Chain Reaction-Based Assays for the Diagnosis of Invasive Fungal Disease in Pediatric Cancer and Hematopoietic Stem Cell Transplantation: A Systematic Review and Meta-Analysis. Clin. Infect. Dis. 2016, 63, 1340-1348. [CrossRef] [PubMed] 
132. Beauvais, A.; Fontaine, T.; Aimanianda, V.; Latgé, J.-P. Aspergillus cell wall and biofilm. Mycopathologia 2014, 178, 371-377. [CrossRef] [PubMed]

133. Fontaine, T.; Beauvais, A.; Loussert, C.; Thevenard, B.; Fulgsang, C.C.; Ohno, N.; Clavaud, C.; Prevost, M.-C.; Latgé, J.-P. Cell wall $\alpha 1-3$ glucans induce the aggregation of germinating conidia of Aspergillus fumigatus. Fungal Genet. Biol. 2010, 47, 707-712. [CrossRef]

134. Latgé, J.-P.; Beauvais, A. Functional duality of the cell wall. Curr. Opin. Microbiol. 2014, 20, 111-117. [CrossRef] [PubMed]

135. Loussert, C.; Schmitt, C.; Prevost, M.-C.; Balloy, V.; Fadel, E.; Philippe, B.; Kauffmann-Lacroix, C.; Latgé, J.-P.; Beauvais, A. In vivobiofilm composition of Aspergillus fumigatus. Cell. Microbiol. 2010, 12, 405-410. [CrossRef] [PubMed]

136. Chai, L.Y.A.; Vonk, A.G.; Kullberg, B.J.; Verweij, P.E.; Verschueren, I.; Van der Meer, J.W.M.; Joosten, L.A.B.; Latgé, J.-P.; Netea, M.G. Aspergillus fumigatus cell wall components differentially modulate host TLR2 and TLR4 responses. Microbes Infect. 2011, 13, 151-159. [CrossRef] [PubMed]

137. Beauvais, A.; Bozza, S.; Kniemeyer, O.; Formosa, C.; Formosa, C.; Balloy, V.; Henry, C.; Roberson, R.W.; Dague, E.; Chignard, M.; et al. Deletion of the $\alpha$-(1,3)-glucan synthase genes induces a restructuring of the conidial cell wall responsible for the avirulence of Aspergillus fumigatus. PLoS Pathog. 2013, 9, e1003716. [CrossRef]

138. Komarova, B.S.; Orekhova, M.V.; Tsvetkov, Y.E.; Beau, R.; Aimanianda, V.; Latgé, J.-P.; Nifantiev, N.E. Synthesis of a pentasaccharide and neoglycoconjugates related to fungal $\alpha-(1 \rightarrow 3)$-glucan and their use in the generation of antibodies to trace Aspergillus fumigatus cell wall. Chemistry 2015, 21, 1029-1035. [CrossRef] [PubMed]

139. Bidula, S.; Kenawy, H.; Ali, Y.M.; Sexton, D.; Schwaeble, W.J.; Schelenz, S. Role of Ficolin-A and Lectin Complement Pathway in the Innate Defense against Pathogenic Aspergillus Species. Infect. Immun. 2013, 81, 1730-1740. [CrossRef] [PubMed]

140. Bidula, S.; Sexton, D.W.; Schelenz, S. Serum opsonin ficolin-A enhances host-fungal interactions and modulates cytokine expression from human monocyte-derived macrophages and neutrophils following Aspergillus fumigatus challenge. Med. Microbiol. Immunol. 2016, 205, 133-142. [CrossRef] [PubMed]

141. Bidula, S.; Sexton, D.W.; Yates, M.; Abdolrasouli, A.; Shah, A.; Wallis, R.; Reed, A.; Armstrong-James, D.; Schelenz, S. H-ficolin binds Aspergillus fumigatus leading to activation of the lectin complement pathway and modulation of lung epithelial immune responses. Immunology 2015, 146, 281-291. [CrossRef] [PubMed]

142. Bidula, S.; Sexton, D.W.; Abdolrasouli, A.; Shah, A.; Reed, A.; Armstrong-James, D.; Schelenz, S. The Serum Opsonin L-ficolin Is Detected in Lungs of Human Transplant Recipients Following Fungal Infections and Modulates Inflammation and Killing of Aspergillus fumigatus. J. Infect. Dis. 2015, 212, 234-246. [CrossRef] [PubMed]

143. Becker, K.L.; Aimanianda, V.; Wang, X.; Gresnigt, M.S.; Ammerdorffer, A.; Jacobs, C.W.; Gazendam, R.P.; Joosten, L.A.B.; Netea, M.G.; Latge, J.P.; et al. Aspergillus Cell Wall Chitin Induces Anti- and Proinflammatory Cytokines in Human PBMCs via the Fc- $\gamma$ Receptor/Syk/PI3K Pathway. mBio 2016, 7, e01823-15. [CrossRef]

144. Dubey, L.K.; Moeller, J.B.; Schlosser, A.; Sorensen, G.L.; Holmskov, U. Chitin enhances serum IgE in Aspergillus fumigatus induced allergy in mice. Immunobiology 2015, 220, 714-721. [CrossRef] [PubMed]

145. O'Dea, E.M.; Amarsaikhan, N.; Li, H.; Downey, J.; Steele, E.; Van Dyken, S.J.; Locksley, R.M.; Templeton, S.P. Eosinophils are Recruited in Response to Chitin Exposure and Enhance Th2-Mediated Immune Pathology in Aspergillus fumigatus infection. Infect. Immun. 2014, 82, 3199-3205. [CrossRef] [PubMed]

146. Lee, M.J.; Gravelat, F.N.; Cerone, R.P.; Baptista, S.D.; Campoli, P.V.; Choe, S.-I.; Kravtsov, I.; Vinogradov, E.; Creuzenet, C.; Liu, H.; et al. Overlapping and distinct roles of Aspergillus fumigatus UDP-glucose 4-epimerases in galactose metabolism and the synthesis of galactose-containing cell wall polysaccharides. J. Biol. Chem. 2014, 289, 1243-1256. [CrossRef] [PubMed]

147. Fontaine, T.; Delangle, A.; Simenel, C.; Coddeville, B.; van Vliet, S.J.; van Kooyk, Y.; Bozza, S.; Moretti, S.; Schwarz, F.; Trichot, C.; et al. Galactosaminogalactan, a new immunosuppressive polysaccharide of Aspergillus fumigatus. PLoS Pathog. 2011, 7, e1002372. [CrossRef] [PubMed]

148. Sheppard, D.C. Molecular mechanism of Aspergillus fumigatus adherence to host constituents. Curr. Opin. Microbiol. 2011, 14, 375-379. [CrossRef] [PubMed] 
149. Lee, M.J.; Liu, H.; Barker, B.M.; Snarr, B.D.; Gravelat, F.N.; Al Abdallah, Q.; Gavino, C.; Baistrocchi, S.R.; Ostapska, H.; Xiao, T.; et al. The Fungal Exopolysaccharide Galactosaminogalactan Mediates Virulence by Enhancing Resistance to Neutrophil Extracellular Traps. PLoS Pathog. 2015, 11, e1005187. [CrossRef]

150. Robinet, P.; Baychelier, F.; Fontaine, T.; Picard, C.; Debré, P.; Vieillard, V.; Latgé, J.-P.; Elbim, C. A Polysaccharide Virulence Factor of a Human Fungal Pathogen Induces Neutrophil Apoptosis via NK Cells. J. Immunol. 2014, 192, 5332-5342. [CrossRef] [PubMed]

151. Gresnigt, M.S.; Bozza, S.; Becker, K.L.; Joosten, L.A.B.; Abdollahi-Roodsaz, S.; van der Berg, W.B.; Dinarello, C.A.; Netea, M.G.; Fontaine, T.; De Luca, A.; et al. A Polysaccharide Virulence Factor from Aspergillus fumigatus Elicits Anti-inflammatory Effects through Induction of Interleukin-1 Receptor Antagonist. PLoS Pathog. 2014, 10, e1003936. [CrossRef]

152. Rambach, G.; Blum, G.; Latgé, J.-P.; Fontaine, T.; Heinekamp, T.; Hagleitner, M.; Jeckström, H.; Weigel, G.; Würtinger, P.; Pfaller, K.; et al. Identification of Aspergillus fumigatus surface components that mediate interaction of conidia and hyphae with human platelets. J. Infect. Dis. 2015, 212, 1140-1149. [CrossRef]

153. Snarr, B.D.; Baker, P.; Bamford, N.C.; Sato, Y.; Liu, H.; Lehoux, M.L.; Gravelat, F.N.; Ostapska, H.; Baistrocchi, S.R.; Cerone, R.P.; et al. Microbial glycoside hydrolases as antibiofilm agents with cross-kingdom activity. Proc. Natl. Acad. Sci. USA 2017, 114, 7124-7129. [CrossRef] [PubMed]

154. Henriet, S.S.V.; van de Sande, W.W.J.; Lee, M.J.; Simonetti, E.; Momany, M.; Verweij, P.E.; Rijs, A.J.M.M.; Ferwerda, G.; Sheppard, D.C.; de Jonge, M.I.; et al. Decreased Cell Wall Galactosaminogalactan in Aspergillus nidulans Mediates Dysregulated Inflammation in the Chronic Granulomatous Disease Host. J. Interferon Cytokine Res. 2016, 36, 488-498. [CrossRef]

155. Perfect, J.R.; Cox, G.M.; Lee, J.Y.; Kauffman, C.A.; de Repentigny, L.; Chapman, S.W.; Morrison, V.A.; Pappas, P.; Hiemenz, J.W.; Stevens, D.A.; et al. The impact of culture isolation of Aspergillus species: A hospital-based survey of aspergillosis. Clin. Infect. Dis. 2001, 33, 1824-1833. [CrossRef]

156. Slesiona, S.; Gressler, M.; Mihlan, M.; Zaehle, C.; Schaller, M.; Barz, D.; Hube, B.; Jacobsen, I.D.; Brock, M. Persistence versus escape: Aspergillus terreus and Aspergillus fumigatus employ different strategies during interactions with macrophages. PLoS ONE 2012, 7, e31223. [CrossRef] [PubMed]

157. Deak, E.; Nelson, M.; Hernández-Rodríguez, Y.; Gade, L.; Baddley, J.; Momany, M.; Steele, C.; Balajee, S.A. Aspergillus terreus accessory conidia are multinucleated, hyperpolarizing structures that display differential dectin staining and can induce heightened inflammatory responses in a pulmonary model of aspergillosis. Virulence 2011, 2, 200-207. [CrossRef] [PubMed]

158. Doering, T.L. How does Cryptococcus get its coat? Trends Microbiol. 2000, 8, 547-553. [CrossRef]

159. Jesus, M.D.; Nicola, A.M.; Chow, S.-K.; Lee, I.R.; Nong, S.; Specht, C.A.; Levitz, S.M.; Casadevall, A. Glucuronoxylomannan, galactoxylomannan, and mannoprotein occupy spatially separate and discrete regions in the capsule of Cryptococcus neoformans. Virulence 2010, 1, 500-508. [CrossRef] [PubMed]

160. Cross, C.E.; Bancroft, G.J. Ingestion of acapsular Cryptococcus neoformans occurs via mannose and $\beta$-glucan receptors, resulting in cytokine production and increased phagocytosis of the encapsulated form. Infect. Immun. 1995, 63, 2604-2611. [PubMed]

161. Feldmesser, M.; Kress, Y.; Novikoff, P.; Casadevall, A. Cryptococcus neoformans is a facultative intracellular pathogen in murine pulmonary infection. Infect. Immun. 2000, 68, 4225-4237. [CrossRef] [PubMed]

162. Alvarez, M.; Casadevall, A. Phagosome extrusion and host-cell survival after Cryptococcus neoformans phagocytosis by macrophages. Curr. Biol. 2006, 16, 2161-2165. [CrossRef] [PubMed]

163. Alvarez, M.; Casadevall, A. Cell-to-cell spread and massive vacuole formation after Cryptococcus neoformans infection of murine macrophages. BMC Immunol. 2007, 8, 16. [CrossRef] [PubMed]

164. Zaragoza, O.; Rodrigues, M.L.; De Jesus, M.; Frases, S.; Dadachova, E.; Casadevall, A. The capsule of the fungal pathogen Cryptococcus neoformans. Adv. Appl. Microbiol. 2009, 68, 133-216. [PubMed]

165. Yauch, L.E.; Mansour, M.K.; Levitz, S.M. Receptor-mediated clearance of Cryptococcus neoformans capsular polysaccharide in vivo. Infect. Immun. 2005, 73, 8429-8432. [CrossRef] [PubMed]

166. Yauch, L.E.; Mansour, M.K.; Shoham, S.; Rottman, J.B.; Levitz, S.M. Involvement of CD14, toll-like receptors 2 and 4, and MyD88 in the host response to the fungal pathogen Cryptococcus neoformans in vivo. Infect. Immun. 2004, 72, 5373-5382. [CrossRef] [PubMed]

167. Monari, C.; Bistoni, F.; Casadevall, A.; Pericolini, E.; Pietrella, D.; Kozel, T.R.; Vecchiarelli, A. Glucuronoxylomannan, a microbial compound, regulates expression of costimulatory molecules and production of cytokines in macrophages. J. Infect. Dis. 2005, 191, 127-137. [CrossRef] [PubMed] 
168. Syme, R.M.; Spurrell, J.; Amankwah, E.K.; Green, F.H.Y.; Mody, C.H. Primary dendritic cells phagocytose Cryptococcus neoformans via mannose receptors and Fc $\gamma$ receptor II for presentation to T lymphocytes. Infect. Immun. 2002, 70, 5972-5981. [CrossRef] [PubMed]

169. Piccioni, M.; Monari, C.; Bevilacqua, S. A critical role for FcgammaRIIB in up-regulation of Fas ligand induced by a microbial polysaccharide. Clin. Exp. Immunol. 2011, 165, 190-201. [CrossRef] [PubMed]

170. Barbosa, F.M.; Fonseca, F.L.; Holandino, C.; Alviano, C.S.; Nimrichter, L.; Rodrigues, M.L. Glucuronoxylomannan-mediated interaction of Cryptococcus neoformans with human alveolar cells results in fungal internalization and host cell damage. Microbes Infect. 2006, 8, 493-502. [CrossRef] [PubMed]

171. Albuquerque, P.C.; Fonseca, F.L.; Dutra, F.F.; Bozza, M.T.; Frases, S.; Casadevall, A.; Rodrigues, M.L. Cryptococcus neoformans glucuronoxylomannan fractions of different molecular masses are functionally distinct. Future Microbiol. 2014, 9, 147-161. [CrossRef] [PubMed]

172. Villena, S.N.; Pinheiro, R.O.; Pinheiro, C.S.; Nunes, M.P.; Takiya, C.M.; DosReis, G.A.; Previato, J.O.; Mendonça-Previato, L.; Freire-de-Lima, C.G. Capsular polysaccharides galactoxylomannan and glucuronoxylomannan from Cryptococcus neoformans induce macrophage apoptosis mediated by Fas ligand. Cell. Microbiol. 2008, 10, 1274-1285. [CrossRef] [PubMed]

173. Chiapello, L.S.; Baronetti, J.L.; Garro, A.P.; Spesso, M.F.; Masih, D.T. Cryptococcus neoformans glucuronoxylomannan induces macrophage apoptosis mediated by nitric oxide in a caspase-independent pathway. Int. Immunol. 2008, 20, 1527-1541. [CrossRef] [PubMed]

174. Monari, C.; Bistoni, F.; Vecchiarelli, A. Glucuronoxylomannan exhibits potent immunosuppressive properties. FEMS Yeast Res. 2006, 6, 537-542. [CrossRef] [PubMed]

175. Grijpstra, J.; Tefsen, B.; van Die, I.; de Cock, H. The Cryptococcus neoformans cap10 and cap59 mutant strains, affected in glucuronoxylomannan synthesis, differentially activate human dendritic cells. FEMS Immunol. Med. Microbiol. 2009, 57, 142-150. [CrossRef] [PubMed]

176. Monari, C.; Pericolini, E.; Bistoni, G.; Casadevall, A.; Kozel, T.R.; Vecchiarelli, A. Cryptococcus neoformans Capsular Glucuronoxylomannan Induces Expression of Fas Ligand in Macrophages. J. Immunol. 2005, 174, 3461-3468. [CrossRef] [PubMed]

177. Yauch, L.E.; Lam, J.S.; Levitz, S.M. Direct Inhibition of T-Cell Responses by the Cryptococcus Capsular Polysaccharide Glucuronoxylomannan. PLoS Pathog. 2006, 2, e120. [CrossRef] [PubMed]

178. Moyrand, F.; Klaproth, B.; Himmelreich, U.; Dromer, F.; Janbon, G. Isolation and characterization of capsule structure mutant strains of Cryptococcus neoformans. Mol. Microbiol. 2002, 45, 837-849. [CrossRef] [PubMed]

179. Janbon, G.; Himmelreich, U.; Moyrand, F.; Improvisi, L.; Dromer, F. Cas1p is a membrane protein necessary for the O-acetylation of the Cryptococcus neoformans capsular polysaccharide. Mol. Microbiol. 2001, 42, 453-467. [CrossRef] [PubMed]

180. Ramos, C.L.; Fonseca, F.L.; Rodrigues, J.; Guimaraes, A.J.; Cinelli, L.P.; Miranda, K.; Nimrichter, L.; Casadevall, A.; Travassos, L.R.; Rodrigues, M.L. Chitin-Like Molecules Associate with Cryptococcus neoformans Glucuronoxylomannan To Form a Glycan Complex with Previously Unknown Properties. Eukaryot. Cell 2012, 11, 1086-1094. [CrossRef] [PubMed]

181. Dong, Z.M.; Murphy, J.W. Cryptococcal polysaccharides bind to CD18 on human neutrophils. Infect. Immun. 1997, 65, 557-563. [PubMed]

182. Pericolini, E.; Cenci, E.; Monari, C.; De Jesus, M.; Bistoni, F.; Casadevall, A.; Vecchiarelli, A. Cryptococcus neoformans capsular polysaccharide component galactoxylomannan induces apoptosis of human T-cells through activation of caspase-8. Cell. Microbiol. 2006, 8, 267-275. [CrossRef] [PubMed]

183. Pericolini, E.; Gabrielli, E.; Cenci, E.; De Jesus, M.; Bistoni, F.; Casadevall, A.; Vecchiarelli, A. Involvement of Glycoreceptors in Galactoxylomannan-Induced T Cell Death. J. Immunol. 2009, 182, 6003-6010. [CrossRef]

184. Pericolini, E.; Gabrielli, E.; Bistoni, G.; Cenci, E.; Perito, S.; Chow, S.-K.; Riuzzi, F.; Donato, R.; Casadevall, A.; Vecchiarelli, A. Role of CD45 Signaling Pathway in Galactoxylomannan-Induced T Cell Damage. PLoS ONE 2010, 5, e12720. [CrossRef] [PubMed]

185. De Jesus, M.; Nicola, A.M.; Frases, S.; Lee, I.R.; Mieses, S.; Casadevall, A. Galactoxylomannan-Mediated Immunological Paralysis Results from Specific B Cell Depletion in the Context of Widespread Immune System Damage. J. Immunol. 2009, 183, 3885-3894. [CrossRef] [PubMed]

186. Moyrand, F.; Fontaine, T.; Janbon, G. Systematic capsule gene disruption reveals the central role of galactose metabolism on Cryptococcus neoformans virulence. Mol. Microbiol. 2007, 64, 771-781. [CrossRef] 
187. Teixeira, P.A.C.; Penha, L.L.; Mendonça-Previato, L.; Previato, J.O. Mannoprotein MP84 mediates the adhesion of Cryptococcus neoformans to epithelial lung cells. Front. Cell Infect. Microbiol. 2014, 4, 106. [CrossRef] [PubMed]

188. Specht, C.A.; Nong, S.; Dan, J.M.; Lee, C.K.; Levitz, S.M. Contribution of glycosylation to T cell responses stimulated by recombinant Cryptococcus neoformans mannoprotein. J. Infect. Dis. 2007, 196, 796-800. [CrossRef]

189. Levitz, S.M.; Specht, C.A. The molecular basis for the immunogenicity of Cryptococcus neoformans mannoproteins. FEMS Yeast Res. 2006, 6, 513-524. [CrossRef] [PubMed]

190. Murphy, J.W. Influence of cryptococcal antigens on cell-mediated immunity. Rev. Infect. Dis. 1988, 10, S432-S435. [CrossRef] [PubMed]

191. Orendi, J.M.; Verheul, A.F.; De Vos, N.M.; Visser, M.R.; Snippe, H.; Cherniak, R.; Vaishnav, V.V.; Rijkers, G.T.; Verhoef, J. Mannoproteins of Cryptococcus neoformans induce proliferative response in human peripheral blood mononuclear cells (PBMC) and enhance HIV-1 replication. Clin. Exp. Immunol. 1997, 107, $293-299$. [CrossRef] [PubMed]

192. Delfino, D.; Cianci, L.; Lupis, E.; Celeste, A.; Petrelli, M.L.; Curró, F.; Cusumano, V.; Teti, G. Interleukin-6 production by human monocytes stimulated with Cryptococcus neoformans components. Infect. Immun. 1997, 65, 2454-2456. [PubMed]

193. Pietrella, D.; Corbucci, C.; Perito, S.; Bistoni, G.; Vecchiarelli, A. Mannoproteins from Cryptococcus neoformans Promote Dendritic Cell Maturation and Activation. Infect. Immun. 2005, 73, 820-827. [CrossRef] [PubMed]

194. Pitzurra, L.; Cherniak, R.; Giammarioli, M.; Perito, S.; Bistoni, F.; Vecchiarelli, A. Early induction of interleukin-12 by human monocytes exposed to Cryptococcus neoformans mannoproteins. Infect. Immun. 2000, 68, 558-563. [CrossRef] [PubMed]

195. Dan, J.M.; Kelly, R.M.; Lee, C.K.; Levitz, S.M. Role of the mannose receptor in a murine model of Cryptococcus neoformans infection. Infect. Immun. 2008, 76, 2362-2367. [CrossRef] [PubMed]

196. Pietrella, D.; Mazzolla, R.; Lupo, P.; Pitzurra, L.; Gomez, M.J.; Cherniak, R.; Vecchiarelli, A. Mannoprotein from Cryptococcus neoformans Promotes T-Helper Type 1 Anticandidal Responses in Mice. Infect. Immun. 2002, 70, 6621-6627. [CrossRef]

197. Datta, K.; Bartlett, K.H.; Baer, R.; Byrnes, E.; Galanis, E.; Heitman, J.; Hoang, L.; Leslie, M.J.; MacDougall, L.; Magill, S.S.; et al. Cryptococcus gattii Working Group of the Pacific Northwest Spread of Cryptococcus gattii into Pacific Northwest region of the United States. Emerg. Infect. Dis. 2009, 15, 1185-1191. [CrossRef] [PubMed]

198. Angkasekwinai, P.; Sringkarin, N.; Supasorn, O.; Fungkrajai, M.; Wang, Y.-H.; Chayakulkeeree, M.; Ngamskulrungroj, P.; Angkasekwinai, N.; Pattanapanyasat, K. Cryptococcus gattii infection dampens Th1 and Th17 responses by attenuating dendritic cell function and pulmonary chemokine expression in the immunocompetent hosts. Infect. Immun. 2014, 82, 3880-3890. [CrossRef] [PubMed]

199. Cheng, P.-Y.; Sham, A.; Kronstad, J.W. Cryptococcus gattii isolates from the British Columbia cryptococcosis outbreak induce less protective inflammation in a murine model of infection than Cryptococcus neoformans. Infect. Immun. 2009, 77, 4284-4294. [CrossRef]

200. Urai, M.; Kaneko, Y.; Ueno, K.; Okubo, Y.; Aizawa, T.; Fukazawa, H.; Sugita, T.; Ohno, H.; Shibuya, K.; Kinjo, Y.; et al. Evasion of Innate Immune Responses by the Highly Virulent Cryptococcus gattii by Altering Capsule Glucuronoxylomannan Structure. Front. Cell Infect. Microbiol. 2015, 5, 101. [CrossRef] [PubMed]

201. Washburn, R.G.; Bryant-Varela, B.J.; Julian, N.C.; Bennett, J.E. Differences in Cryptococcus neoformans capsular polysaccharide structure influence assembly of alternative complement pathway C3 convertase on fungal surfaces. Mol. Immunol. 1991, 28, 465-470. [CrossRef]

202. Holbrook, E.D.; Rappleye, C.A. Histoplasma capsulatum pathogenesis: Making a lifestyle switch. Curr. Opin. Microbiol. 2008, 11, 318-324. [CrossRef] [PubMed]

203. Schlech, W.F.; Wheat, L.J.; HO, J.L.; French, M.L.; Weeks, R.J.; Kohler, R.B.; Deane, C.E.; Eitzen, H.E.; Band, J.D. Recurrent urban histoplasmosis, Indianapolis, Indiana, 1980-1981. Am. J. Epidemiol. 1983, 118, 301-312. [CrossRef] [PubMed]

204. Rappleye, C.A.; Engle, J.T.; Goldman, W.E. RNA interference in Histoplasma capsulatum demonstrates a role for $\alpha$-(1,3)-glucan in virulence. Mol. Microbiol. 2004, 53, 153-165. [CrossRef] [PubMed]

205. Rappleye, C.A.; Eissenberg, L.G.; Goldman, W.E. Histoplasma capsulatum $\alpha$-(1,3)-glucan blocks innate immune recognition by the $\beta$-glucan receptor. Proc. Natl. Acad. Sci. USA 2007, 104, 1366-1370. [CrossRef] [PubMed] 
206. Edwards, J.A.; Alore, E.A.; Rappleye, C.A. The yeast-phase virulence requirement for $\alpha$-glucan synthase differs among Histoplasma capsulatum chemotypes. Eukaryot. Cell 2011, 10, 87-97. [CrossRef] [PubMed]

207. Garfoot, A.L.; Shen, Q.; Wüthrich, M.; Klein, B.S.; Rappleye, C.A. The Eng1 $\beta$-Glucanase Enhances Histoplasma Virulence by Reducing $\beta$-Glucan Exposure. mBio 2016, 7, e01388-15. [CrossRef] [PubMed]

208. Sepulveda, V.E.; Williams, C.L.; Goldman, W.E. Comparison of Phylogenetically Distinct Histoplasma Strains Reveals Evolutionarily Divergent Virulence Strategies. mBio 2014, 5, e01376-14. [CrossRef] [PubMed]

209. Garfoot, A.L.; Dearing, K.L.; VanSchoiack, A.D.; Wysocki, V.H.; Rappleye, C.A. Eng1 and Exg8 Are the Major $\beta$-Glucanases Secreted by the Fungal Pathogen Histoplasma capsulatum. J. Biol. Chem. 2017, 292, 4801-4810. [CrossRef] [PubMed]

210. Perfect, J.R. The antifungal pipeline: A reality check. Nat. Rev. Drug Discov. 2017. [CrossRef] [PubMed]

211. Mann, P.A.; McLellan, C.A.; Koseoglu, S.; Si, Q.; Kuzmin, E.; Flattery, A.; Harris, G.; Sher, X.; Murgolo, N.; Wang, H.; et al. Chemical Genomics-Based Antifungal Drug Discovery: Targeting Glycosylphosphatidylinositol (GPI) Precursor Biosynthesis. ACS Infect. Dis. 2015, 1, 59-72. [CrossRef]

212. Johnson, M.A.; Cartmell, J.; Weisser, N.E.; Woods, R.J.; Bundle, D.R. Molecular Recognition of Candida albicans $(1 \rightarrow 2)$ - $\beta$-Mannan Oligosaccharides by a Protective Monoclonal Antibody Reveals the Immunodominance of Internal Saccharide Residues. J. Biol. Chem. 2012, 287, 18078-18090. [CrossRef]

213. Schmidt, C.S.; White, C.J.; Ibrahim, A.S.; Filler, S.G.; Fu, Y.; Yeaman, M.R.; Edwards, J.E., Jr.; Hennessey, J.P., Jr. NDV-3, a recombinant alum-adjuvanted vaccine for Candida and Staphylococcus aureus, is safe and immunogenic in healthy adults. Vaccine 2012, 30, 7594-7600. [CrossRef] [PubMed]

214. Bamford, N.C.; Snarr, B.D.; Gravelat, F.N.; Little, D.J.; Lee, M.J.; Chabot, J.C.; Geller, A.M.; Baptista, S.D.; Baker, P.; Robinson, H.; et al. Sph3 is a glycoside hydrolase required for the biosynthesis of galactosaminogalactan in Aspergillus fumigatus. J. Biol. Chem. 2015, 290, 27438-27450. [CrossRef] [PubMed]

215. Pericolini, E.; Alunno, A.; Gabrielli, E.; Bartoloni, E.; Cenci, E.; Chow, S.-K.; Bistoni, G.; Casadevall, A.; Gerli, R.; Vecchiarelli, A. The Microbial Capsular Polysaccharide Galactoxylomannan Inhibits IL-17A Production in Circulating T Cells from Rheumatoid Arthritis Patients. PLoS ONE 2013, 8, e53336. [CrossRef] [PubMed]

(C) 2017 by the authors. Licensee MDPI, Basel, Switzerland. This article is an open access article distributed under the terms and conditions of the Creative Commons Attribution (CC BY) license (http:/ / creativecommons.org/licenses/by/4.0/). 